\title{
Expansion in $\mathrm{CD} 39^{+} \mathrm{CD} 4^{+}$Immunoregulatory T Cells and Rarity of Th17 Cells in HTLV-1 Infected Patients Is Associated with Neurological Complications
}

\author{
Fabio E. Leal ${ }^{1,2,3 \uparrow}$, Lishomwa C. Ndhlovu ${ }^{1,2 \uparrow}$, Aaron M. Hasenkrug ${ }^{1}$, Fernanda R. Bruno ${ }^{4}$, \\ Karina I. Carvalho ${ }^{4}$, Harry Wynn-Williams ${ }^{2}$, Walter K. Neto ${ }^{5,6}$, Sabri S. Sanabani ${ }^{3}$, Aluisio C. Segurado ${ }^{3}$, \\ Douglas F. Nixon ${ }^{1}$, Esper G. Kallas ${ }^{3,4 *}$ \\ 1 The Division of Experimental Medicine, Department of Medicine, University of California San Francisco, San Francisco, California, United States of America, 2 Hawaii \\ Center of AIDS, Department of Tropical Medicine, John A. Burns School of Medicine, University of Hawaii, Honolulu, Hawaii, United States of America, 3 Deparment of \\ Infectious Diseases, School of Medicine, University of Sao Paulo, Sao Paulo, Brazil, 4 Division of Clinical Immunology and Allergy, University of Sao Paulo Medical School, \\ Sao Paulo, Brazil, 5 Molecular Biology Laboratory, Fundação Pró-Sangue, Hemocentro de São Paulo, Brazil, 6 Department of Translational Medicine, Federal University of \\ São Paulo, São Paulo, Brazil
}

\begin{abstract}
HTLV-1 infection is associated with several inflammatory disorders, including the neurodegenerative condition HTLV-1associated myelopathy/tropical spastic paraparesis (HAM/TSP). It is unclear why a minority of infected subjects develops HAM/TSP. CD4 ${ }^{+}$T cells are the main target of infection and play a pivotal role in regulating immunity to HTLV and are hypothesized to participate in the pathogenesis of HAM/TSP. The CD39 ectonucleotidase receptor is expressed on CD4 ${ }^{+} \mathrm{T}$ cells and based on co-expression with CD25, marks $T$ cells with distinct regulatory $\left(C D 39^{+} \mathrm{CD} 25^{+}\right)$and effector $\left(C D 39^{+} \mathrm{CD} 25^{-}\right)$function. Here, we investigated the expression of CD39 on CD4 ${ }^{+} \mathrm{T}$ cells from a cohort of HAM/TSP patients, HTLV-1 asymptomatic carriers (AC), and matched uninfected controls. The frequency of CD39 $9^{+} \mathrm{CD} 4^{+} \mathrm{T}$ cells was increased in HTLV-1 infected patients, regardless of clinical status. More importantly, the proportion of the immunostimulatory $\mathrm{CD}_{3}{ }^{+} \mathrm{CD} 25^{-} \mathrm{CD}^{+} \mathrm{T}$-cell subset was significantly elevated in HAM/TSP patients as compared to AC and phenotypically had lower levels of the immunoinhibitory receptor, PD-1. We saw no difference in the frequency of $C D 39^{+} \mathrm{CD} 25^{+}$regulatory (Treg) cells between AC and HAM/TSP patients. However, these cells transition from being anergic to displaying a polyfunctional cytokine response following HTLV-1 infection. CD39 ${ }^{-} \mathrm{CD} 25^{+} \mathrm{T}$ cell subsets predominantly secreted the inflammatory cytokine IL-17. We found that HAM/TSP patients had significantly fewer numbers of IL-17 secreting CD4 ${ }^{+} \mathrm{T}$ cells compared to uninfected controls. Taken together, we show that the expression of CD39 is upregulated on CD4 ${ }^{+} \mathrm{T}$ cells HAM/TSP patients. This upregulation may play a role in the development of the proinflammatory milieu through pathways both distinct and separate among the different CD39 T cell subsets. CD39 upregulation may therefore serve as a surrogate diagnostic marker of progression and could potentially be a target for interventions to reduce the development of HAM/ TSP.
\end{abstract}

Citation: Leal FE, Ndhlovu LC, Hasenkrug AM, Bruno FR, Carvalho Kl, et al. (2013) Expansion in CD39 CD4 ${ }^{+}$Immunoregulatory T Cells and Rarity of Th17 Cells in HTLV-1 Infected Patients Is Associated with Neurological Complications. PLoS Negl Trop Dis 7(2): e2028. doi:10.1371/journal.pntd.0002028

Editor: Fatah Kashanchi, George Mason University, United States of America

Received June 28, 2012; Accepted December 7, 2012; Published February 7, 2013

Copyright: (C) 2013 Leal et al. This is an open-access article distributed under the terms of the Creative Commons Attribution License, which permits unrestricted use, distribution, and reproduction in any medium, provided the original author and source are credited.

Funding: Support for this work was provided by National Institute of Allergies and Infectious Diseases and by funds from the National Institutes of Health University of California, San Francisco-Gladstone Institute of Virology \& Immunology Center for AIDS Research (P30 AI027763). Additional support was provided by the Fundação de Amparo a Pesquisa do Estado de São Paulo (04/15856-9/Kallas and 2010/05845-0/Kallas and Nixon and 11/12297-2/Sanabani), the John E. Fogarty International Center (D43 TW00003), National Center for Research Resources (5P20RR016467-11) and the National Institute of General Medical Sciences (8P20GM103466-11) from the National Institutes of Health. The funders had no role in study design, data collection and analysis, decision to publish, or preparation of the manuscript.

Competing Interests: The authors have declared that no competing interests exist.

*E-mail: esper.kallas@usp.br

- These authors contributed equally to this work as first authors.

\section{Introduction}

Human T-lymphotropic virus type 1 (HTLV-1) has been estimated to infect 10-20 million worldwide [1]. The majority of infected individuals remain asymptomatic carriers of this retrovirus for life. However, $2 \%$ to $3 \%$ of HTLV-1-infected individuals develop a neurodegenerative disorder characterized by a progressive spastic paraparesis called HTLV-1-Associated Myelopathy/ Tropical Spastic Paraparesis (HAM/TSP) [2,3]. Other chronic inflammatory conditions including arthritis, uveitis, polymyositis, and Sjögren syndrome have also been associated with HTLV-1 infection $[4,5,6,7]$. In endemic areas, $2 \%$ to $6 \%$ of seropositive individuals develop Adult T-cell Leukemia (ATL) [8]. In the absence of efficient treatment options that modify disease progression and protective vaccination, understanding the causative mechanisms of disease progression is paramount to develop preventative and treatment options.

The reasons why persons with HTLV-1 infection develop these complications appear to be multiple and complex, and the mechanisms for progression have not been fully deter- 


\section{Author Summary}

Human T-lymphotropic virus type 1 (HTLV-1) has been estimated to infect 10-20 million worldwide. The majority of infected individuals are asymptomatic, however, $2 \%$ to $3 \%$ develop a neurodegenerative disorder called HTLV-1associated myelopathy/tropical spastic paraparesis (HAM/ TSP). The reasons why persons with HTLV-1 develop these complications appear to be multiple and complex. Cellular immune response has been implicated in the development of inflammatory alterations in these patients, however the pathogenic mechanisms for disease progression remain unclear. Regulatory $\mathrm{CD}^{+} \mathrm{T}$ cells (Treg) and Th17 cells derive from a common progenitor and conflicting results regarding frequency and function are found in the development of HAM/TSP. The expression of the CD39 ectoenzyme, a molecule that can mediate immunostimulatory and inhibitory effects, is useful to define IL-17 secreting cell populations, suppressive $C D 4^{+} \mathrm{T}$ cells and $\mathrm{CD}^{+} \mathrm{T}$ cells with immunostimulatory properties. The interplay of these T-cell subsets may reveal important aspects of HAM/TSP pathogenesis. In this study, we performed an evaluation of the immunoregulatory $\mathrm{CD}^{+}$ T-cell subsets defined by CD39 expression including Th17 cells. Our results present phenotypic and functional alterations in the $\mathrm{CD}^{+} \mathrm{T}$ cell profile that could account for the transition from asymptomatic status to HAM/TSP, predicting clinical disease risk and tracking disease progression.

mined. Several mechanisms have been postulated to account for disease progression to HAM/TSP such as age, gender, transmission mode and proviral load levels $[9,10,11,12,13]$. Cellular immune response has been implicated in the control of HTLV-1 infection as well as in the development of inflammatory alterations in these patients. The viral protein Tax is the immunodominant peptide recognized by $\mathrm{CD}^{+} \mathrm{T}$ cells in patients with HTLV-1. Analyses of the role of HTLV-1 Tax-specific CD8 ${ }^{+} \mathrm{T}$ cells in the control of HTLV-1 infection show that strong $\mathrm{CD}^{+} \mathrm{T}$ cytolytic activity correlates negatively with proviral load, but it occurs regardless of disease status $[14,15]$. The higher frequencies of HTLV-1Tax-specific IFN- $\gamma^{+} \mathrm{CD}^{+} \mathrm{T}$ cells are positively associated with the frequency of HTLV-1-infected cells in HAM/TSP patients suggesting that $\mathrm{CD}^{+} \mathrm{T}$ cell responses may neither control viral replication nor prevent disease progression [16,17]. Such high frequency of HTLV-1-Tax-specific IFN- $\gamma$-producing $\mathrm{CD}^{+} \mathrm{T}$ cells, with low expression of inhibitory receptors in peripheral blood and in the central nervous system appear to contribute to the inflammatory alterations seen in HAM/TSP patients $[18,19,20,21]$.

Recently, the viral protein HTLV-1 basic leucine zipper (HBZ), encoded by an anti-sense strand of the HTLV-1 provirus [22,23], may better serve as proxy for disease progression than Tax. HBZ expression down-regulates Tax expression [23], inhibit NF- $\kappa \mathrm{B}$ classical pathway activation and yet promotes $\mathrm{CD} 4^{+} \mathrm{T}$-cell proliferation in transgenic mice $[24,25]$. HBZ-specific CD8 ${ }^{+} \mathrm{T}$ cells, though not as frequent as Tax-specific $\mathrm{CD}^{+} \mathrm{T}$ cells, appear to correlate with proviral load and disease progression, represents a potential target for HAM/TSP progression and provide important clues for disease progression $[26,27]$. These studies, however, may only partially account for the transition from an asymptomatic status to the development of HAM/TSP.

HTLV-1 infects several human cell types [28,29], but primarily $\mathrm{CD}^{+} \mathrm{T}$ cells $[30,31]$. Under specific conditions, $\mathrm{CD}^{+} \mathrm{T}$ cells differentiate towards Th1, Th2, Treg and Th17 lineages $[32,33,34]$. Distinct CD4 ${ }^{+}$T-cell subsets play a pivotal role on the immune response. Regulation of HTLV-1 infection and $\mathrm{CD}^{+}{ }^{+} \mathrm{T}$-cell subsets frequency and function may be influenced by the expression of viral proteins Tax and HBZ that activates promoters of several cellular genes and induces $\mathrm{CD}^{+} \mathrm{T}$ cell replication [25]. Furthermore, $H B Z$ transcription has been reported to correlate with proviral load, inflammatory markers and disease severity $[27,35]$. Higher frequencies of virus-specific IFN- $\gamma$-producing $\mathrm{CD} 4^{+} \mathrm{T}$ cells are observed in cerebrospinal fluid (CSF) and sera of HAM/TSP patients compared to HTLV1 asymptomatic carriers with similar proviral load [36], suggesting a role for $\mathrm{CD}^{+} \mathrm{T}$ cells in neural damage. Understanding immune regulatory aspects and $\mathrm{CD}^{+} \mathrm{T}$-cell responses to HTLV-1 could clarify the complex pathogenesis of HAM/TSP in the midst of strong anti-HTLV-1 immunity. Specific $\mathrm{CD}^{+}{ }^{+} \mathrm{T}$-cell subsets play a key role in the regulation of immune responses and inflammatory diseases $[37,38]$ and modulate the function of $\mathrm{CD}^{+} \mathrm{T}$ cells, including Tax-specific $\mathrm{CD}^{+} \mathrm{T}$ cells cytolytic activity [39]. Two antagonistic subsets involved in the pathway of tolerance and immunity, regulatory $\mathrm{CD}^{+} \mathrm{T}$ cells (Treg) and Th17 cells, derives from a common progenitor [40] and conflicting results regarding frequency and function are found in studies of Tregs and Th17 in the development of HAM/TSP [39,41,42,43,44,45].

The CD39 ectoenzyme can mediate immunostimulatory and inhibitory effects by releasing adenosine through its enzymatic activity [46]. Our previous study and those by others have shown that expression of CD39 serves as a novel marker to identify suppressive $\mathrm{CD}^{+} \mathrm{T}$ cells [47], a $\mathrm{CD}^{+}$T-cell subset with immunostimulatory properties [48] and can further distinguish between IL-17 secreting cell populations [49]. The interplay of these T-cell subsets may reveal important aspects of HAM/TSP pathogenesis. Furthermore, depletion of Th17 cells in the peripheral blood and in the gut is detrimental to control of HIV-1 infection, another retrovirus with many similarities to HTLV-1 acquisition but with divergent clinical outcomes $[50,51,52]$. It is unclear whether Th17 cells may contribute to the immune response to $\mathrm{HTLV}-1$ replication as well as to the proinflammatory milieu seen in HAM/TSP patients.

In this study we performed an evaluation of the immunoregulatory $\mathrm{CD} 4^{+} \mathrm{T}$-cell subsets defined by CD39 expression including Th17 cells in patients enrolled in an HTLV-1 clinic in Sao Paulo, Brazil. We hypothesized that changes in the $\mathrm{CD}^{+} \mathrm{T}$ cell compartment would lead to alterations in $\mathrm{T}$-cell functions that may be involved in HTLV-1 disease progression. Our results present phenotypic and functional alterations in the $\mathrm{CD} 4^{+} \mathrm{T}$-cell profile based on CD39 expression that could account for the transition from an asymptomatic status to HAM/TSP, predicting clinical disease risk and possibly track disease progression.

\section{Materials and Methods}

\section{Ethics Statement}

All human participants of this study voluntarily signed an informed consent approved by the institutional review board of the University of Sao Paulo (IRB \#0855/08) Sao Paulo, Brazil. Clinical investigation procedures were conducted according to the principles expressed in the Declaration of Helsinki (http://www. wma.net/en/30publications/10policies/b3/index.html) 
Table 1. Characteristics of study participants.

\begin{tabular}{|c|c|c|c|c|}
\hline & Uninfected ( $n=19)$ & Asymptomatic carrier $(n=24)$ & HAM/TSP ${ }^{\dagger}(n=13)$ & $P$ value \\
\hline Age, median (IQR $\left.{ }^{\ddagger}\right)$ & $39(29-52)$ & $47(36-55)$ & $54(36-61)$ & NS \\
\hline Gender (male/female) & $6 / 13$ & 7/17 & $5 / 8$ & \\
\hline CD4+ T cells, per ml (mean \pm SD* $^{* *}$ & $1217 \pm 419.4$ & $1152 \pm 432.3$ & $1305 \pm 606.6$ & NS \\
\hline CD4+ $\mathrm{T}$ cell percentage (mean $\pm \mathrm{SD}$ ) & $48.75 \pm 7.16$ & $54.6 \pm 10.92$ & $54.54 \pm 7.80$ & NS \\
\hline HTLV-1* proviral load, copies $/ 10^{3}$ cells (mean \pm SD) & N/A & $68.91 \pm 124.61$ & $249.38 \pm 302.42$ & 0.0026 \\
\hline
\end{tabular}

HAM/TSP: HTLV-1 associated myelopathy/tropical spastic paraparesis;

*HTLV-1: Human T Lymphotropic Virus Type 1;

IQR: Interquartile Range, 25\%-75\%;

**Standard Deviation.

doi:10.1371/journal.pntd.0002028.t001

\section{Study Participants}

We enrolled 37 patients from the HTLV-1 Outpatient Clinic at the University of Sao Paulo, Brazil. They were invited to participate in a longitudinal cohort of HTLV-1-infected subjects after signing a written informed consent approved by the University of Sao Paulo's Institutional Review Board (\#0855/ 08). This cohort includes 24 asymptomatic carriers (AC) and 13 patients with neurological complications related to HTLV-1 infection denominated HTLV-1 Associated Myelopathy/Tropical Spastic Paraparesis (HAM/TSP). The clinical status was determined based on WHO criteria for HTLV-1 associated diseases [53]. The majority of the patients were female $(67 \%), 17$ in the asymptomatic group and $8 \mathrm{HAM} / \mathrm{TSP}$ patients, with a median age of 47 (Interquartile Range [IQR], 36-55) and 54 (IQR, 36-61) years respectively.

We enrolled 19 age- and gender-matched healthy volunteers without laboratory evidence of HTLV-1, Hepatitis B, Hepatitis C, and HIV infections, with similar demographic characteristics as the HTLV-1-infected participants (See Table 1).

Blood samples were obtained and processed with Ficoll-Paque PLUS (Amersham Pharmacia Biotech, Uppsala, Sweden) gradient centrifugation and peripheral-blood mononuclear cells (PBMC) were isolated and cryopreserved in $10 \%$ DMSO in FBS. This study was approved by the institutional review board and ethical committee of the University of Sao Paulo (\#0855/08).

\section{Flow Cytometry Assessment}

Cryopreserved PBMC were thawed in RPMI 1640 with 10\% FBS and washed in FACS buffer (PBS with $0.5 \%$ bovine serum albumin, 2 mM EDTA). Phenotypic detection was performed on $10^{6}$ cells by incubation with conjugated anti-CD3, CD4, CD25, CCR4 (BD Biosciences, San Diego, CA), PD-1 (Biolegend, San Diego, CA) and CD39 (eBioscience, San Diego, CA) for 30 minutes on ice. For intracellular staining, cells were fixed and permeabilized prior to staining with conjugated antibodies against FoxP3, IFN- $\gamma$, IL-10, IL-2 (BD Biosciences), CTLA-4 (Immunotech, Marseille, France), TNF- $\alpha$ (eBioscience) and IL-17 (Biolegend, San Diego, CA).

Proviral load and mRNA assessment. HTLV-1 proviral DNA was extracted from PBMCs using a commercial kit (Qiagen $\mathrm{GmbH}$, Hilden Germany) following the manufacturer's instructions. The extracted DNA was used as a template to amplify a fragment of $158 \mathrm{bp}$ from the viral tax region using previously published primers [54]. The SYBR green real-time PCR assay was carried out in $25 \mu \mathrm{l}$ PCR mixture containing $10 \times$ Tris $(\mathrm{pH} 8.3$; Invitrogen, Brazil), $1.5 \mathrm{mM} \mathrm{MgCl}_{2}, 0.2 \mu \mathrm{M}$ of each primer, $0.2 \mathrm{mM}$ of each dNTPs, SYBR Green (18.75 Units $/ \mathrm{r} \times \mathrm{n}$;
Cambrex Bio Science, Rockland, ME) and 1 unit of platinum Taq polymerase (Invitrogen, Brazil). The amplification was performed in the Bio-Rad iCycler iQ system using an initial denaturation step at $95^{\circ} \mathrm{C}$ for 2 minutes, followed by 50 cycles of $95^{\circ} \mathrm{C}$ for 30 seconds, $57^{\circ} \mathrm{C}$ for 30 seconds, and $72^{\circ} \mathrm{C}$ for 30 seconds. The human housekeeping $\beta$-globin gene primers GH20 and PC04 [55] were used as an internal control calibrator. For each run, standard curves for the value of HTLV-1 tax were generated from MT-2 cells of $\log _{10}$ dilutions (from $10^{5}$ to $10^{0}$ copies). The threshold cycle for each clinical sample was calculated by defining the point at which the fluorescence exceeded a threshold limit. Each sample was assayed in duplicate and the mean of the two values was considered as the copy number of the sample. The amount of HTLV-1 proviral load was calculated as follows: copy number of HTLV-1 (tax) per 1,000 cells $=($ copy number of HTLV-1 tax)/(copy number of $\beta$ globin/2) $\times 1000$ cells. The method could detect 1 copy per $10^{3}$ PBMC.

For the mRNA quantification assays, RNA was extracted using QIAamp RNA Blood Mini Kit (Qiagen) following the manufacturer's instructions and at a final $50 \mu \mathrm{l}$ elution. The transcription levels of Tax and HBZ and internal reference $\beta$-Actin were measured by The Power SYBR Green RNA-to-C $\mathrm{C}_{\mathrm{T}}$ 1-Step kit (Life Technologies, Carlsbad, CA) using the StepOnePlus Real-Time PCR System (Life Technologies). Tax and HBZ specific primers were used to measure the respective mRNA expression level as described previously [27]. $\beta$-actin was used as a housekeeping control to calculate $2^{-\Delta \Delta \mathrm{Ct}}$ relative expression as previously described [56]. This method allows measuring the relative expression of each gene to an endogenous control, and normalizes measurements as has been previously shown [57].

\section{ELISPOT Assays}

MAIPS4510 Elispot plates (Millipore, Danvers, MA) were coated with anti-IL-17 or anti-IFN- $\gamma 10 \mathrm{mg} / \mathrm{ml}$ (Mabtech, Nacka Strand, Sweden) in PBS, $50 \mathrm{ml} /$ well for one hour at room temperature. After three washes with PBS, PBMC $\left(1 \times 10^{5}\right.$ cells/ well) and Phorbol 12-myristate 12-acetate (PMA) and ionomycin (Ion) (Sigma, St Louis) were added, with a final volume of $200 \mu \mathrm{l} /$ well. Plates were incubated at $37^{\circ} \mathrm{C}$ in $5 \% \mathrm{CO}_{2}$ for $16-20$ hours. After washing with phosphate-buffered saline (PBS) plus $0.1 \%$ Tween 20 (PBST), biotinylated anti-IL-17 or anti-IFN- $\gamma(1 \mathrm{mg} /$ $\mathrm{ml}$ ) (Mabtech), antibodies were added to the appropriate wells in PBS $0.1 \%$ Tween $1 \%$ BSA (PBSTB) for 30 minutes at room temperature. Plates were washed again three times with PBST, and alkaline phosphatase-conjugated streptavidin (Jackson Immunoresearch, West Grove, PA) was added (50 $\mathrm{ml}$ of 1:1,000 dilution in PBSTB) and incubated for $30 \mathrm{~min}$ at room temper- 
ature. Plates were washed in PBST, incubated with blue substrate (Vector Labs, Burlingame, CA) until spots were clearly visible, then rinsed with tap water. When plates were dry, spots were counted using an automated ELISPOT reader. Experiments run in duplicate for IL-17 and IFN- $\gamma$ detection. Results were mediumsubtracted and normalized to $10^{6}$ cells. IFN- $\gamma$ spots were considered positive controls.

\section{Statistical Analysis}

Statistical analysis was performed by using GraphPad Prism statistical software (GraphPad Software, San Diego, CA). Nonparametric statistical tests were used throughout the analyses. The Mann-Whitney $U$ was used for comparison tests and the Spearman rank test were used for correlation analyses.

\section{Results}

\section{Higher Frequency of CD39 Expressing CD4 ${ }^{+} \mathrm{T}$ Cells Subsets in HAM/TSP Infection}

The evaluation of $\mathrm{CD}^{+} \mathrm{T}$ cells subsets as defined by the expression of CD39 and CD25 has revealed novel functional populations that redefine suppressor $\mathrm{T}$ cells expressing FoxP3 [47,58,59], delineate Th17 cells and identify a population of CD39 expressing $\mathrm{T}$ cells with immunostimulatory properties called "inducer" cells $[48,59,60]$. The expression of these markers in HTLV-1 remains undefined.

We examined, by flow cytometry, the pattern of expression of CD39 and CD25 in CD4 ${ }^{+} \mathrm{T}$ cells of 19 uninfected subjects, 24 HTLV-1 asymptomatic carriers and 13 HAM/TSP patients. Since the transcription factor FoxP3 serves to define suppressor $\mathrm{CD} 4^{+} \mathrm{T}$ cells, we first determined its distribution within the $\mathrm{CD} 39^{+} \mathrm{CD} 4^{+} \mathrm{T}$ cells. Based on our gating strategy and in line with our previous study [48], we confirmed that the distribution of FoxP3 within the CD4 ${ }^{+}$ T-cell subsets using CD39 and CD25 $\left(\mathrm{CD} 39^{+} \mathrm{FoxP}^{+} \mathrm{CD}_{25}{ }^{+}\right.$and $\mathrm{CD} 39^{+} \mathrm{FoxP}^{+} \mathrm{CD} 25^{-}$and $\mathrm{CD} 39^{-} \mathrm{FoxP}^{+} \mathrm{CD}_{2} 5^{+}$) did not change irrespective of HTLV-1 infection (data not shown). We observed that the frequencies of $\mathrm{CD} 39^{+} \mathrm{CD} 25^{-} \mathrm{CD} 4^{+} \mathrm{T}$ cells were significantly higher in HAM/TSP compared to AC and uninfected subjects (Fig. 1A,B). Similarly, the numbers of CD $39^{+} \mathrm{CD} 25^{-} \mathrm{CD} 4^{+} \mathrm{T}$ cells were significantly higher in HAM/TSP patients compared to uninfected subjects (Fig. 1C). Significant higher frequencies of CD $39^{+} \mathrm{CD} 25^{+} \mathrm{CD} 4^{+} \mathrm{T}$ cells were found in $\mathrm{AC}$ and HAM/TSP patients compared to uninfected subjects, but the frequencies between the two groups of HTLV-1 infected patients were not significantly different (Fig. 1D). The numbers of CD $39^{+} \mathrm{CD} 25^{+} \mathrm{CD} 4^{+}$ $\mathrm{T}$ cells were also significantly increased between HAM/TSP patients compared to uninfected subjects (Fig. 1E). We observed no differences in the absolute $\mathrm{CD} 4^{+} \mathrm{T}$ cell count (Fig. S2A), frequency (Fig. S2B), and number (Fig. S2C) of CD39- CD2 $5^{+} \mathrm{CD} 4^{+} \mathrm{T}$ cells between uninfected donors, AC, and HAM/TSP patients. We and others have observed that $\mathrm{T}$ regulatory cells can be further defined by the low expression of CD127 and FoxP3 [61,62]. To further define the proportion of regulatory $\mathrm{T}$ cells subsets in HTLV-1 infection, we used a combination of antibodies anti-FoxP3, CD127, and CD25. We determined that phenotypically defined regulatory $\left(\mathrm{CD} 127 \mathrm{loCD} 25^{+} \mathrm{FoxP}^{+}{ }^{+} \mathrm{CD}^{+}{ }^{\mathrm{T}}\right.$ cells were also elevated in HTLV1 infection using this combination of markers. (Fig. S1).

The high frequencies of $\mathrm{CD} 39^{+} \mathrm{CD} 25^{+} \mathrm{CD} 4^{+} \mathrm{T}$ cells in $\mathrm{AC}$ and HAM/TSP subjects reinforce the idea of induced Treg differentiation in HTLV-1 infection while the high frequency of $\mathrm{CD} 9^{+} \mathrm{CD} 25^{-} \mathrm{CD}^{+} \mathrm{T}$ cells only in HAM/TSP patients may contribute to the proinflammatory milieu seen in HAM/TSP and represent a marker of disease progression.
Changes in the Expression of CCR4, CTLA-4 and PD-1 among the CD39 Expression CD4 T Cells in HAM/TSP

CTLA-4 is essential for regulatory T-cell suppressive function as blockade of CTLA-4 expression abrogates Treg function [63,64]. GCR4, a chemokine receptor selectively expressed on Th2, Th17 and Tregs, has been shown to be highly expressed by HTLV-1infected cells [65]. Furthermore, CCR4 expressing CD25 ${ }^{+} \mathrm{CD} 4^{+}$ $\mathrm{T}$ cells are functionally altered in HAM/TSP patients, producing high levels of IFN- $\gamma$ [44]. In an effort to further characterize the two immunoregulatory $\mathrm{T}$ cell populations defined by CD39 and CD25 expression, we evaluated the expression of CTLA, CGR4 and PD- 1 among these subsets. We observed that CD $39^{+} \mathrm{CD} 25^{-}$ $\mathrm{CD}^{+} \mathrm{T}$ cells had the highest expression of CCR4 whereas the $\mathrm{CD} 25^{+} \mathrm{CD} 39^{+} \mathrm{CD} 4^{+} \mathrm{T}$ cells had greatest co-expression of CCR4 and CTLA-4 among uninfected subjects (Fig. 2A). In HTLV-1infected subjects (AG and HAM/TSP), the levels of $\mathrm{CCR}^{+}$ $\mathrm{CTLA}^{+} \mathrm{CD}^{+} \mathrm{T}$ cells among the $\mathrm{CD} 39^{+} \mathrm{CD} 25^{+} \mathrm{CD} 4^{+} \mathrm{T}$ cells significantly declined $(\mathrm{p}=0.0159)$ compared to uninfected controls (Fig. 2B).

Increased PD-1 expression has been shown to mark $\mathrm{T}$ cell activation and dysfunction $[66,67]$, but its expression has also been used to discriminate Treg subsets [68]. We measured surface expression of PD- 1 among the different $\mathrm{CD} 4^{+} \mathrm{T}$ cells and compared the expression among the three population groups according to CD25 and CD39 expression. We observed differential expression of PD-1 levels with $\mathrm{CD} 39^{+} \mathrm{CD} 25^{+} \mathrm{CD} 4^{+} \mathrm{T}$ cells (regulatory) having higher expression of PD-1 in HAM/TSP patients, $(\mathrm{p}=0.0189)$ (Fig. $\mathrm{S} 3 \mathrm{~A}, \mathrm{~B}$ ), whereas the $\mathrm{CD} 39^{+} \mathrm{CD} 25^{-} \mathrm{CD} 4^{+} \mathrm{T}$ cells (inducer) significantly expressed lower levels of PD-1 in HAM/TSP infected patients compared to asymptomatic controls, $(p=0.0317)$ (Fig. S3 B). These data suggest that HTLV-1 infection alters the phenotypic repertoire of $\mathrm{CD} 4$ regulatory $\mathrm{T}$ cells to less anergic state with those patients with HAM/TSP and expand a population of CD $39^{+} \mathrm{CD} 25^{-} \mathrm{CD}^{+} \mathrm{T}$ cells with lower PD-1 levels indicating a potential for even greater $\mathrm{T}$-cell activity.

\section{Direct Association of $\mathrm{CD} 39^{+} \mathrm{CD} 25^{-} \mathrm{CD} 4^{+} \mathrm{T}$ Cells with HTLV-1 Proviral Load in HAM/TSP but not with AC Subjects}

High levels of HTLV-1 proviral load levels have been associated to variable Treg frequency as well as reduced HTLV-1-specific CD8 $^{+}$T-cell lytic efficiency and frequency [14,39,54]. Because HTLV-1 infection promotes $\mathrm{T}$-cell activation and proliferation [69] and proviral load levels are associated with $\mathrm{CD}^{+}{ }^{+} \mathrm{T}$-cell clonal expansion [70], we wished to assess if there is an association between proviral load and the CD39 expressing CD4 ${ }^{+}$T-cell subsets in 24 HTLV-1 asymptomatic carriers and 13 HAM/TSP patients. Frequency and number of $\mathrm{CD} 39^{+} \mathrm{CD} 25^{-} \mathrm{CD} 4^{+} \mathrm{T}$ cells from HAM/TSP patients but not from HTLV-1 asymptomatic carriers are associated with HTLV-1 proviral load levels (Fig. 3A,B). There was no association between proviral load and the frequency (Fig. S4A) or numbers (Fig. S4B) of CD39 CD $25^{+}$ $\mathrm{CD} 4^{+} \mathrm{T}$ cells. Overall this data suggests that CD $39^{+} \mathrm{CD} 25^{-} \mathrm{CD} 4^{+}$ $\mathrm{T}$ cells may contribute to the increased rate of $\mathrm{CD}^{+} \mathrm{T}$-cell proliferation and consequently higher levels of HTLV-1 proviral load in HAM/TSP patients.

\section{Reduction in IL-17 Production in HAM/TSP Patients}

Th17 cells have a pivotal role in many autoimmune and inflammatory conditions, including Multiple Sclerosis (MS). Besides, CD39 ${ }^{+}$Tregs, a T-cell subset with increased frequency among HTLV-1-infected patients, suppress Th17 cells in healthy individuals but are dysfunctional in MS [49], a neurodegenerative 
A

Uninfected

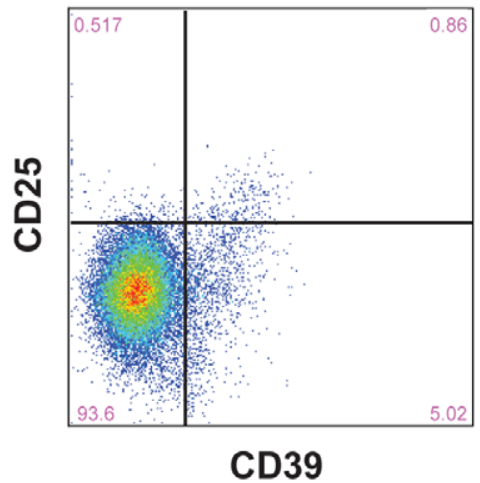

AC

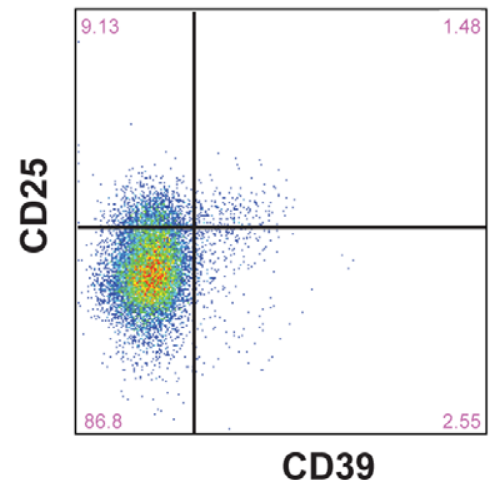

HAM/TSP

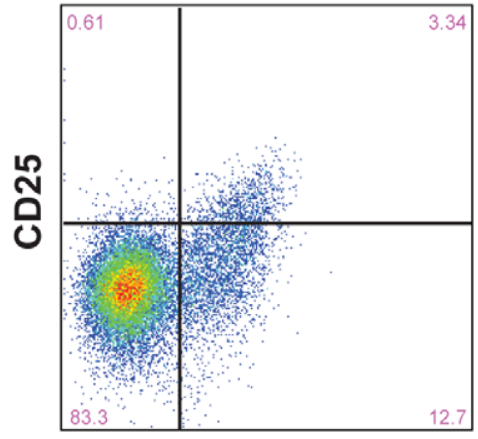

CD39
B
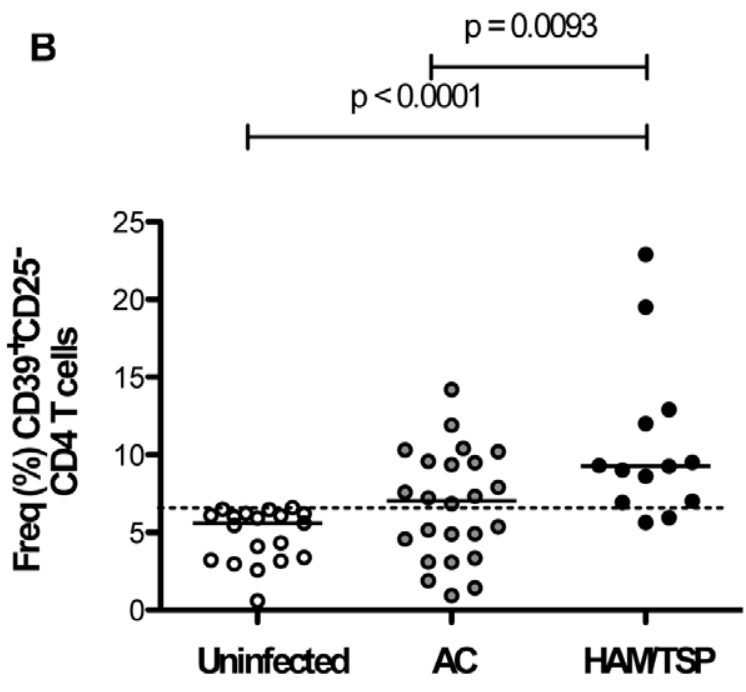

D
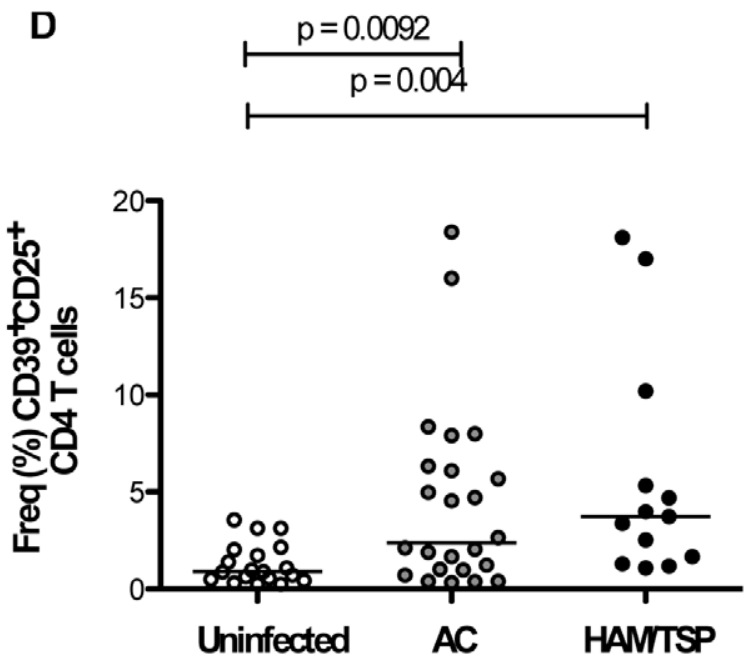

C
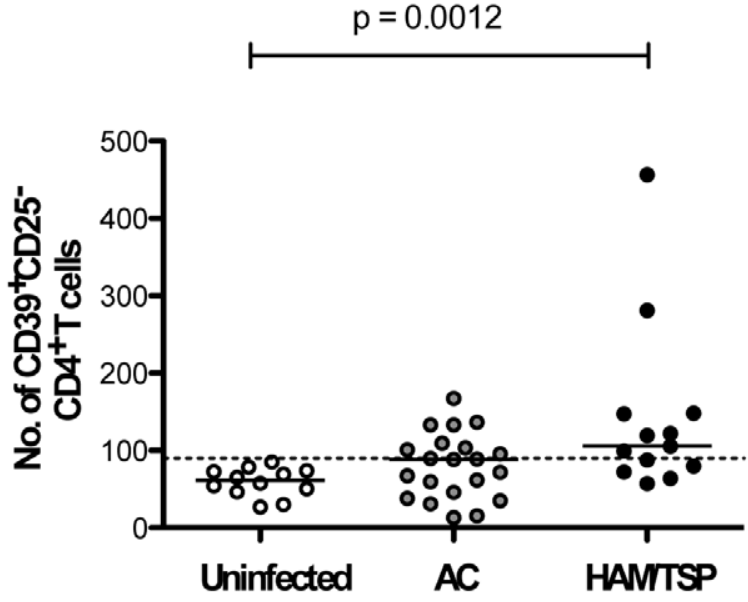

E
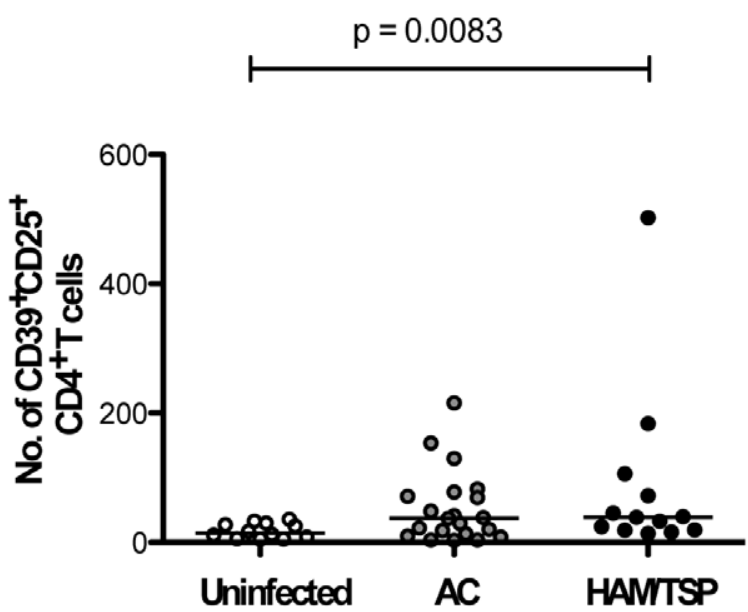

Figure 1. CD25 and CD39 expression in CD4 ${ }^{+}$T cells. Compare results from HAM/TSP patients, HTLV-1 asymptomatic carriers (AC) and uninfected subjects. The statistical difference was deemed significant using a Mann-Whitney $\mathrm{U}$ test analysis if $\mathrm{p}<0.05$. Horizontal bars denote median values. (A) CD39 and CD25 expression in CD4 ${ }^{+} \mathrm{T}$ cells from one representative uninfected donor, one HTLV-1-infected asymptomatic carrier and one HAM/TSP patient. (B) Proportion of $\mathrm{CD} 39^{+} \mathrm{CD} 25^{-} \mathrm{CD} 4^{+} \mathrm{T}$ cells. Dotted line represents higher levels of $\mathrm{CD} 39^{+} \mathrm{CD} 25^{-} \mathrm{CD} 4^{+} \mathrm{T}$ cells in uninfected subjects. (C) Number of CD39+CD25 $5^{-} \mathrm{CD} 4 \mathrm{~T}$ cells. (D) Proportion of $\mathrm{CD} 39^{+} \mathrm{CD} 25^{+} \mathrm{CD} 4^{+} \mathrm{T}$ cells. (E) Number of $\mathrm{CD} 39^{+} \mathrm{CD} 25^{+} \mathrm{CD} 4^{+} \mathrm{T}$ cells. doi:10.1371/journal.pntd.0002028.g001 
A

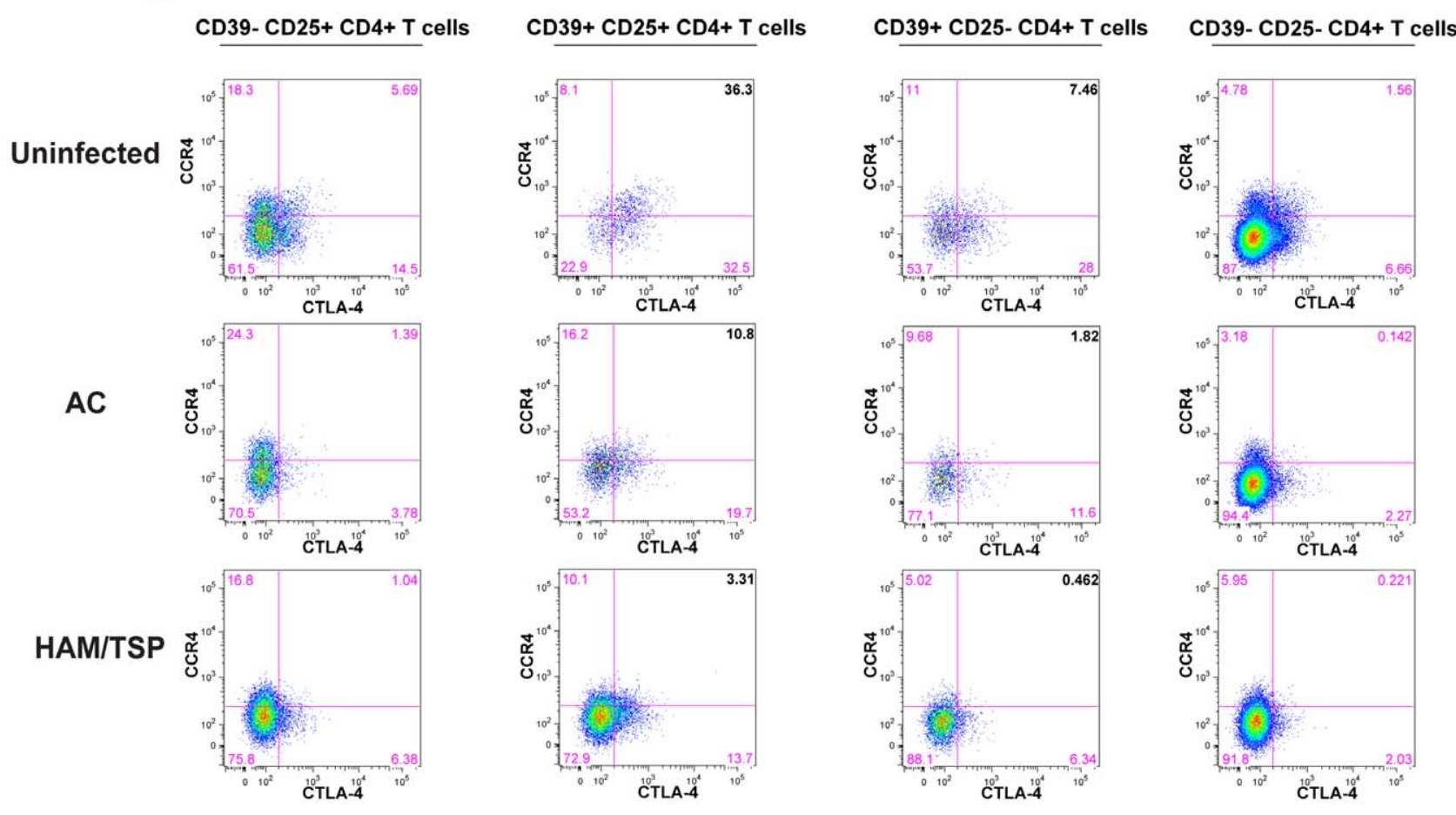

B
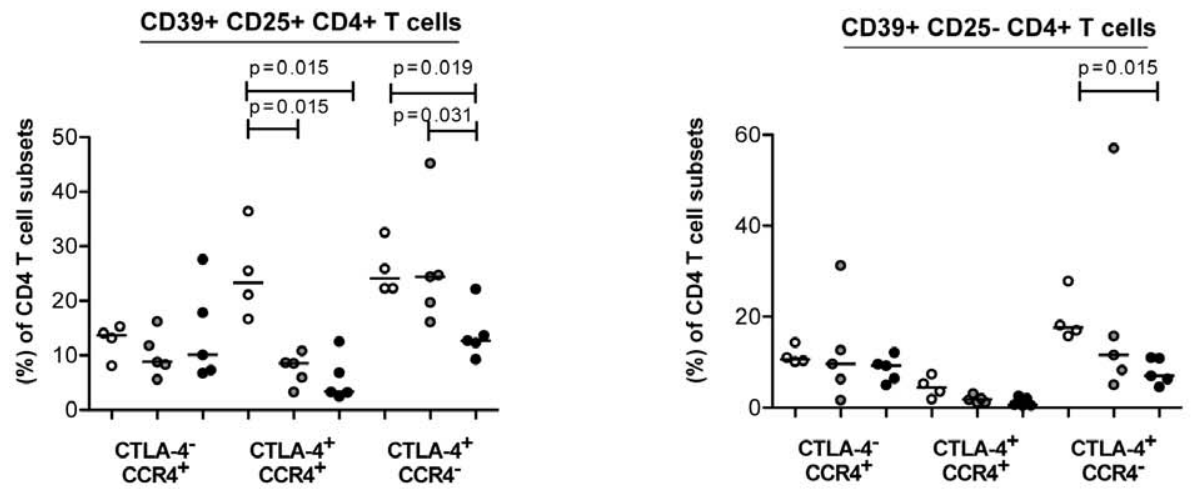

Figure 2. Expression of CTLA-4 and CCR4 in CD4 ${ }^{+}$T-cell subsets based on CD39 and CD25 expression. The statistical difference was deemed significant using a Mann-Whitney $U$ test analysis if $p<0.05$. Horizontal bars denote median values. (A) CTLA-4 and CCR4 expression on CD4 ${ }^{+}$ T cells from one representative uninfected donor, one HTLV-1-infected-asymptomatic carrier and one HAM/TSP patient. (B) Proportion of expression of CTLA-4 and CCR4 in CD39 $9^{+} \mathrm{CD} 25^{+}$and $\mathrm{CD} 39^{+} \mathrm{CD} 25^{-} \mathrm{CD} 4^{+}$T cells of uninfected donors, AC and HAM/TSP patients. doi:10.1371/journal.pntd.0002028.g002

disorder with some clinical similarities to HAM/TSP. Little is known about IL-17 production in HTLV-1 infection. It has been reported that expression of IL-17 mRNA is induced by Tax in HTLV-1 infected T-cell lines [43] and increased in periodontal tissue of HTLV-1-infected subjects with periodontitis [71]. However, IL-17 production from a specific $\mathrm{CD} 4^{+}$T-cell subset is reduced among HAM/TSP patients [44].

We therefore assessed the proportion of IL-17 secreting cells using PBMCs from $18 \mathrm{HTLV}-1$ infected patients (8 asymptomatic carriers and $10 \mathrm{HAM} / \mathrm{TSP}$ ) and 9 uninfected subjects stimulated with PMA and ionomycin in an ELISPOT assay. We found a significant smaller number of IL-17 secreting cells in HAM/TSP patients compared to uninfected subjects and a trend towards a reduced number of IL-17 secreting cells compared to HTLV-1 asymptomatic carriers (Fig. 4A, B).

We also found a significant smaller Th17/CD $39^{+} \mathrm{CD} 25^{-}$T-cell ratio in HAM/TSP patients as compared to HTLV-1-infected asymptomatic carriers, considering the number of IL-17 secreting cells and the frequency or number of CD $39^{+} \mathrm{CD} 25^{-} \mathrm{CD} 4^{+} \mathrm{T}$ cells (Fig. S 5A). A similar reduction was found when we analyzed the Th17/CD $39^{+} \mathrm{CD} 25^{+}$ratio in HAM/TSP patients and compared to HTLV-1-infected asymptomatic carriers, considering the number of IL-17 secreting cells and the frequency or the number of $\mathrm{CD} 39^{+} \mathrm{CD} 25^{+} \mathrm{CD} 4^{+} \mathrm{T}$ cells (Fig. S 5B). 
A

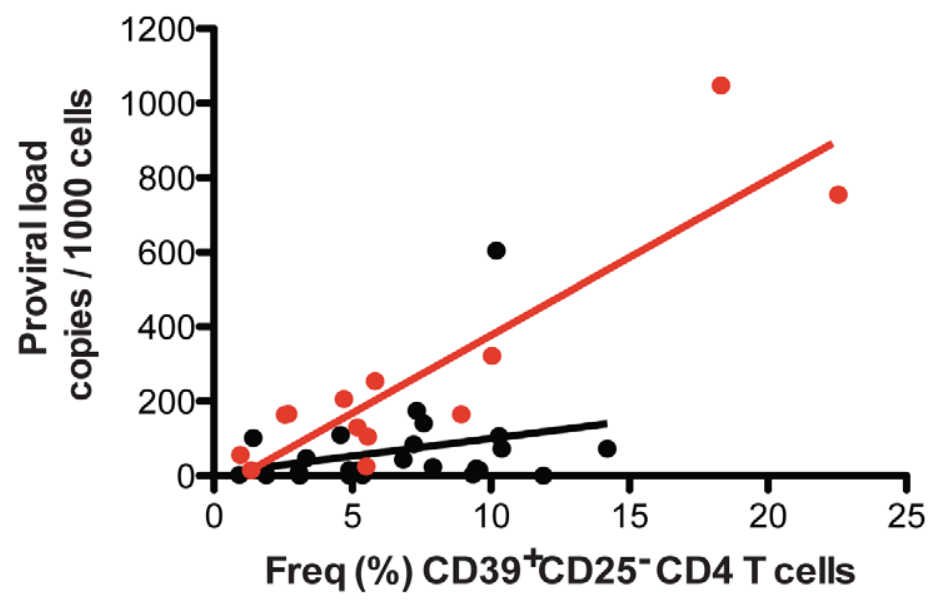

- $\mathrm{AC}$

- $\mathrm{HAM} / \mathrm{TSP}$

$r=0.294$

$r=0.725$

$\mathrm{p}=\mathrm{NS}$

$\mathrm{p}=0.005$

B

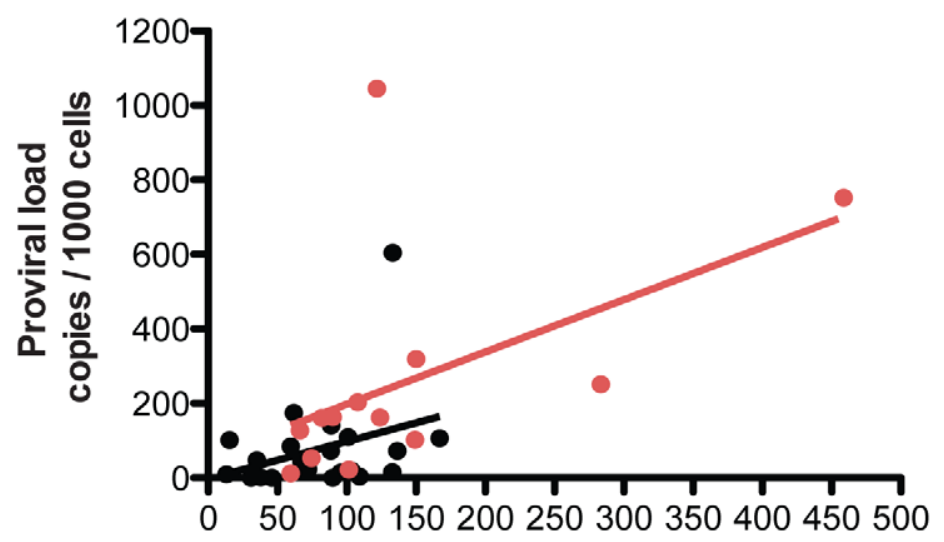

- $\mathrm{AC}$

- $\mathrm{HAM} / \mathrm{TSP}$

$r=0.2816$

$r=0.6923$

$\mathrm{p}=\mathrm{NS}$

$\mathrm{p}=0.008$

\section{No. of CD39 ${ }^{+} \mathrm{CD}^{25} 5^{-} \mathrm{CD} 4 \mathrm{~T}$ cells}

Figure 3. Association between HTLV-1 proviral load and $\mathrm{CD} 39^{+} \mathrm{CD} 25^{-} \mathrm{CD4}^{+}$T cells in HAM/TSP patients. Frequency of $\mathrm{CD} 39^{+} \mathrm{CD} 25^{-}$ $\mathrm{CD}^{+} \mathrm{T}$ cells $(\mathrm{A})$ and number of $\mathrm{CD} 39^{+} \mathrm{CD} 25^{-} \mathrm{CD} 4^{+} \mathrm{T}$ cells $(\mathrm{B})$ were plotted against proviral load of $\mathrm{AC}$ and HAM/TSP patients. The statistical difference was deemed significant using a two-tailed Spearman test analysis if $\mathrm{p}<0.05$. doi:10.1371/journal.pntd.0002028.g003

Increased IFN- $\gamma$, TNF- $\alpha{ }^{+} \mathrm{IL}-2^{+}$Double Positive $\mathrm{CD} 39^{+} \mathrm{CD} 25^{+} \mathrm{CD}^{+} \mathrm{T}$ Cells and Reduced IL-17 Expression in HAM/TSP Patients

HAM/TSP patients appears to have $\mathrm{CD}^{+} \mathrm{T}$ cells that are conditioned to produce IFN- $\gamma$ [36]. Conflicting data regarding IL17 production in HTLV-1 infected subjects and a possible role along with IFN- $\gamma$ in the proinflammatory milieu observed in HAM/ TSP patients led us to investigate the production of inflammatory cytokines of $\mathrm{CD}^{+}{ }^{+} \mathrm{T}$ cells from 9 uninfected, 8 HTLV-1 asymptomatic carriers and $10 \mathrm{HAM} / \mathrm{TSP}$ patients. $\mathrm{CD} 4^{+} \mathrm{T}$ cells subsets from HAM/TSP subjects $\left(\mathrm{CD} 39^{-} \mathrm{CD} 25^{+} \mathrm{CD} 4^{+} \mathrm{T}\right.$ cells) showed significant reduced IL-17 levels when compared to uninfected subjects (Fig. 5B), confirming our results from ELISPOT assays.

Also, we found a significant increased IFN- $\gamma$ production among $\mathrm{CD}_{3}{ }^{+} \mathrm{CD} 25^{+} \mathrm{CD} 4{ }^{+} \mathrm{T}$ cells from HAM/TSP patients compared to HTLV-1 asymptomatic carriers and uninfected subjects (Fig. 5C). We also observed increased levels of IFN- $\gamma$ in CD $39^{+} \mathrm{CD} 25^{-} \mathrm{CD} 4^{+}$ $\mathrm{T}$ cells in HAM/TSP subjects compared to HTLV-1 seronegative individuals (Figure 5G). We next determined the proportion of TNF- $\alpha$ and IL-2 producing $\mathrm{CD} 4^{+} \mathrm{T}$ cells in uninfected subjects, HTLV-1 asymptomatic carriers and HAM/TSP patients (Fig. 6 $\mathrm{A}, \mathrm{B}, \mathrm{C})$. Interestingly, we found a significant increased frequency of TNF- $\alpha^{+}$IL- $2^{+}$producing cells in the $\mathrm{CD} 39^{+} \mathrm{CD} 25^{+} \mathrm{CD} 4^{+} \mathrm{T}$ cells compartment among HAM/TSP patients compared to HTLV-1 asymptomatic carriers and uninfected subjects (Fig. 6D). This CD4 ${ }^{+}$ T-cell subset has a suppressive phenotype and does not produce significant amounts of IFN- $\gamma$ TNF- $\alpha$ and IL-2 in uninfected subjects, suggesting that these immunostimulatory and/or immunoregulatory CD39 expressing T cell subsets may participate in the pro-inflammatory milieu that could potentially lead to the progression to HAM/TSP.

HBZ but not Tax Expression Associates with the Expanded $C D 39^{+} \mathrm{CD}_{25} 5^{-} \mathrm{CD} 4^{+} \mathrm{T}$-Cell Subset Seen in HAM/ TSP

The trans-acting viral regulatory protein Tax (Tax) gene and the HTLV-1 basic leucine zipper (HBZ) gene, an antisense 


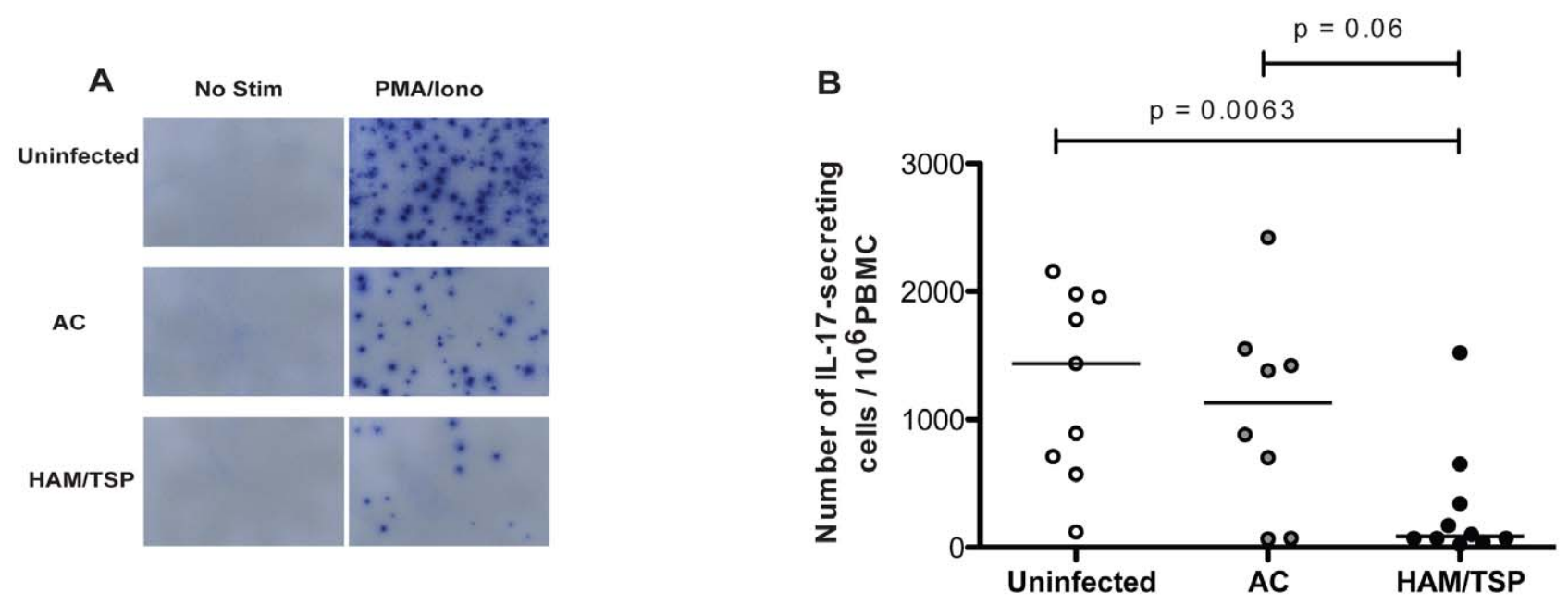

Figure 4. Measurement of IL-17 secretion of PBMC by ELISPOT. Experiments run in duplicate. Results are medium-subtracted and normalized to $10^{6}$ cells. The statistical difference was deemed significant using a Mann-Whitney $U$ test analysis if $p<0.05$. Horizontal bars indicate median values. (A) ELISPOT data from 1 representative experiment of each group of subjects. (B) Number of IL-17 secreting cells in PBMC from 9 uninfected donors, 8 HTLV-1 asymptomatic carriers and 10 HAM/TSP patients.

doi:10.1371/journal.pntd.0002028.g004

transcribed mRNA promote proliferation and maintenance of HTLV-1 infected T cells and are reported to be oncogenic factors in ATL induction $[25,27,72,73]$. Both have been identified as important targets implicated in the pathogenesis of HAM/TSP. To assay whether increased proviral load is responsible for the expansion of $\mathrm{CD} 39^{+} \mathrm{CD} 4^{+} \mathrm{T}$-cell subsets, we evaluated protein Tax expression by flow and gene expression of $H B Z$ and Tax as a proxy to determine HTLV-1 replication. HTLV-1-infected subjects were therefore assessed for Tax expression on the $\mathrm{CD} 4^{+}$ T cells subsets based on CD39 and CD25 expression. We observed Tax expression was represented in the CD25 expressing CD4 ${ }^{+} \mathrm{T}$ cells subsets in both CD39 and CD39 lacking cells. There was no difference in the Tax expression representation between $\mathrm{AC}$ and HAM/TSP (Fig. 7A,B). HAM/TSP patients presented with a significantly higher level of HBZ mRNA compared to HTLV-1 asymptomatic carriers (Fig. 8A). This result is comparable to results previously reported by Saito et al, [27]. We assessed the relationship between $H B Z$ transcription levels and the CD39 expressing immunoregulatory $\mathrm{T}$ cells. $H B Z$ transcription levels positively associated with both $\mathrm{CD} 39^{+} \mathrm{CD} 25^{+}$and CD $39^{+} \mathrm{CD} 25^{-} \mathrm{CD} 4^{+} \mathrm{T}$ cells (Fig. $8 \mathrm{~B}, \mathrm{C}$ ). These data suggest that Tax expression is absent among the $\mathrm{CD} 39^{+} \mathrm{CD} 25^{-} \mathrm{CD} 4^{+} \mathrm{T}$ cells that are expanded in HAM/TSP and may not be the driver for this expansion. Our findings further suggest that $H B Z$ is an important viral protein that is associated with expansion of these immunoregulatory $\mathrm{T}$ cells populations as disease progresses.

\section{Discussion}

In this study, we have demonstrated that CD39 serves as a marker of the profound phenotypic and functional changes in $\mathrm{CD} 4^{+}$ T cells in HTLV-1 that potentially contribute to the development of HAM/TSP. Several important findings have been revealed from this work. First, an increased frequency of the immunostimulatory $\left(\mathrm{CD} 39^{+} \mathrm{CD} 25^{-}\right) \mathrm{CD}^{+} \mathrm{T}$ cells in HAM/TSP patients and its association with proviral load, a marker of disease status. These cells retain lower levels of PD-1 reflecting a phenotypic and functional shift in T-cell activity. Second, the reduced number of Th17 cells combined with conversion of $\mathrm{CD}^{+} \mathrm{T}$ cells with suppressive phenotype $\left(\mathrm{CD}_{3} 9^{+} \mathrm{CD} 25^{+}\right)$to those with increased IFN- $\gamma$, TNF- $\alpha$ and IL-2 production in patients with HAM/TSP. These data suggest a novel role for CD39 as a useful marker and potential mediator of the dysregulation of the $\mathrm{CD}^{+}$T-cell subsets in symptomatic HTLV-1 infection. Our interpretations lead us to conclude that these changes occur to either counterbalance the proinflammatory effect of $\mathrm{HTLV}-1$ infection or directly participate in the immunopathology leading to HAM/TSP.

The high frequency of a T cell subset with immunostimulatory properties [48] in HAM/TSP patients, but not in asymptomatic carriers, suggests that $\mathrm{CD} 39^{+} \mathrm{CD} 25^{-} \mathrm{CD} 4^{+} \mathrm{T}$ cells contribute to the increased $\mathrm{CD}^{+}{ }^{+} \mathrm{T}$-cell proliferation seen in HAM/TSP despite concomitant expansion of $\mathrm{CD} 4^{+} \mathrm{T}$ cells with suppressive phenotype $\left(\mathrm{CD} 39^{+} \mathrm{CD} 25^{+}\right)$. In patients who develop HAM/TSP, such expansion may be insufficient to control the deleterious effect of the virus-induced inflammatory milieu. Whether HTLV-1 infection induces an increase or reduction in regulatory $\mathrm{CD}^{+} \mathrm{T}$ cells $[39,42,54,74,75]$ remains unresolved. This may be attributable to the different phenotypic combination of markers used to define suppressive regulatory T cells. Defining and identifying suppressive $\mathrm{T}$ cells is a major challenge in the context of autoimmunity or infection. Activated $\mathrm{CD}^{+}{ }^{+} \mathrm{T}$ cells may also express most markers used to define Treg including FoxP3, the forkhead transcription factor [76]. FoxP3 expression is subject to transient expression by $\mathrm{T}$ cell activation and is localized in the nucleus [77], which limits functional analyses after intranuclear staining.

Initial studies with functional analysis of $\mathrm{CD} 4^{+} \mathrm{CD} 25^{+} \mathrm{T}$ cells suggested that Tregs are dysfunctional in HAM/TSP and Tax expression has direct inhibitory effect on FoxP3 expression and function $[42,54,75,78]$. However, it has recently been demonstrated that an increased frequency of FoxP3 expression in $\mathrm{CD} 4^{+}$ $\mathrm{T}$ cells in HTLV-1 infection persists. One possible mechanism is the high plasma levels of CG chemokine ligand 22 (CCL22) the CCR4 ligand, apparently inducing FoxP3 expression [74]. Our results support this latter hypothesis and that despite an increased frequency of FoxP3 or T-regulatory cells $\left(\mathrm{CD} 25^{+} \mathrm{CD} 4^{+}\right)$, these cells transition from being anergic to displaying a polyfunctional cytokine feature and may contribute to the proinflammatory millieu leading to HAM/TSP.

Based on our findings, we propose that CD39 serves as a novel marker to delineate the phenotype and the role of suppressive $\mathrm{CD} 4^{+}$ 
A

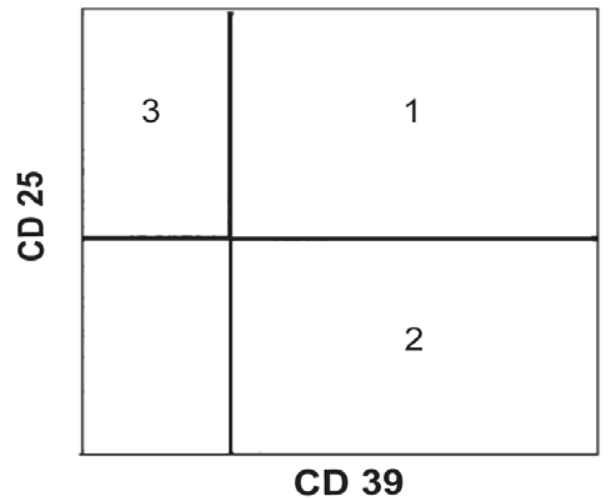

CD 39

$$
\begin{aligned}
& 1=\text { CD39+CD25+ } \\
& 2=\text { CD39+CD25- } \\
& 3=\text { CD39-CD25+ }
\end{aligned}
$$

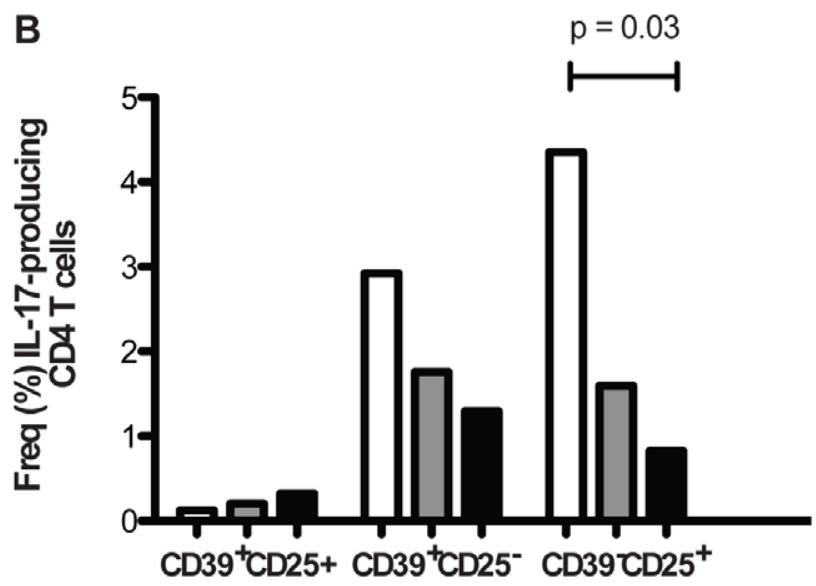

\section{$\square$ Uninfected \\ $\square$ AC \\ HAM/TSP}

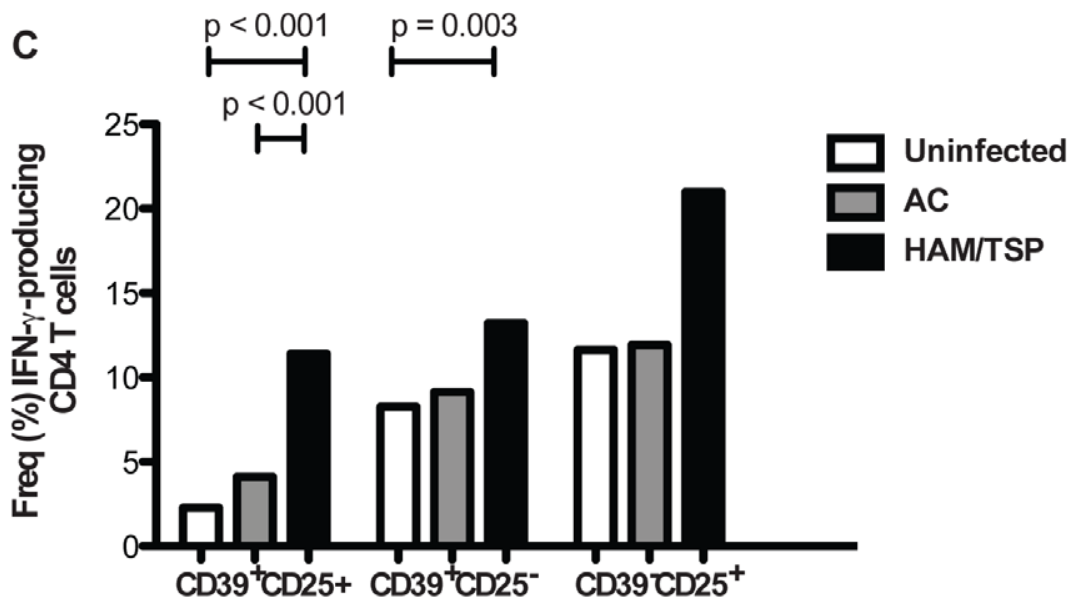

Figure 5. IL-17 and IFN- $\gamma$ production by CD4 ${ }^{+} \mathbf{T}$ cells subsets. Subsets were numbered according to CD39 and CD25 expression (A): $1=\mathrm{CD}^{+} 9^{+} \mathrm{CD} 25^{+} ; 2=\mathrm{CD}_{3} 9^{+} \mathrm{CD} 25^{-} ; 3=\mathrm{CD}^{-} 9^{-} \mathrm{CD} 25^{+}$. Graph shows median of proportion of (B) IL-17-producing CD4 ${ }^{+} \mathrm{T}$ cells and (C) IFN- $\gamma$-producing $\mathrm{CD}^{+} \mathrm{T}$ cells subsets after PMA and ionomycin stimulation on PBMCs from 9 uninfected, 8 HTLV-1-infected asymptomatic carriers and 10 HAM/TSP patients. The statistical difference was deemed significant using a Mann-Whitney $U$ test analysis if $p<0.05$. doi:10.1371/journal.pntd.0002028.g005 
A
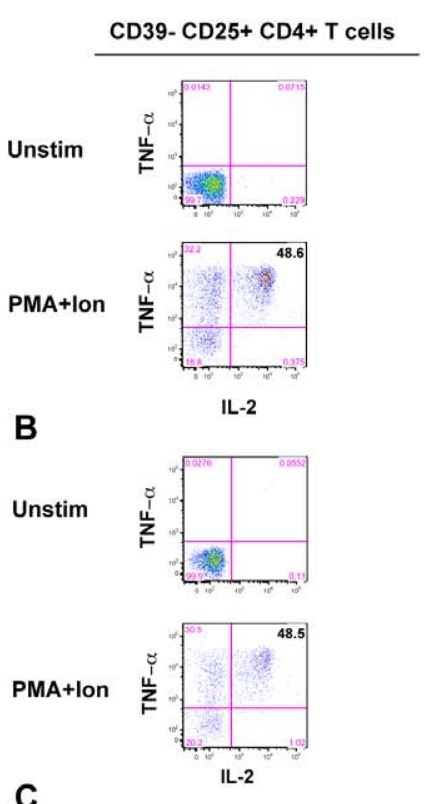

C

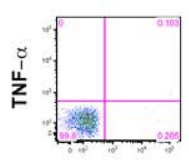

PMA+lon

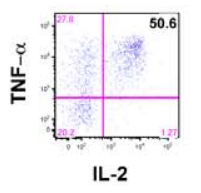

D CD39- CD25+ CD4+ T cells

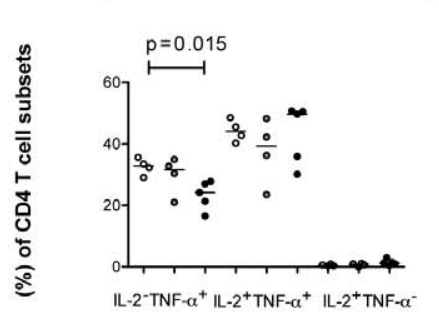

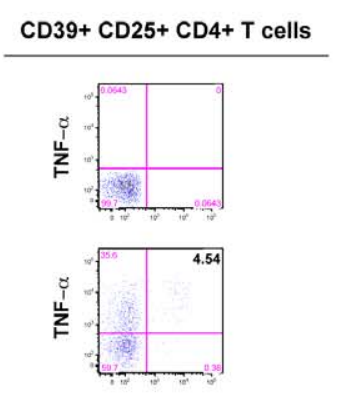

IL-2
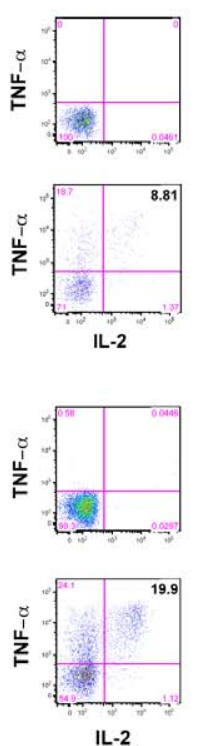
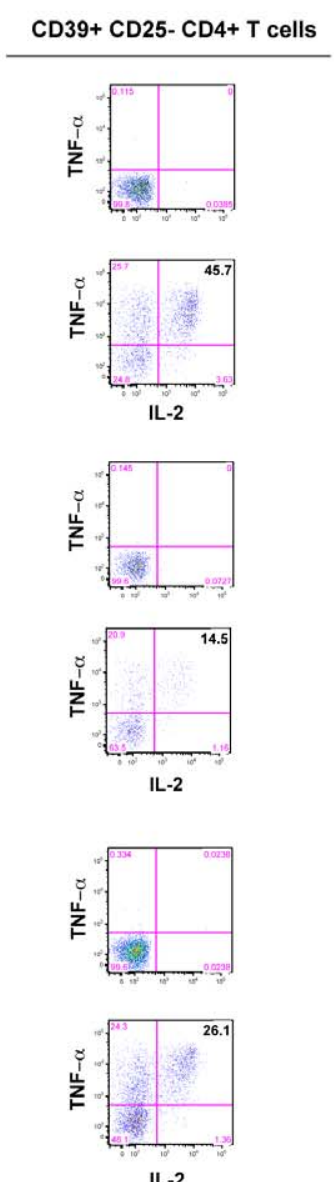

IL-2
CD39- CD25- CD4+ T cells
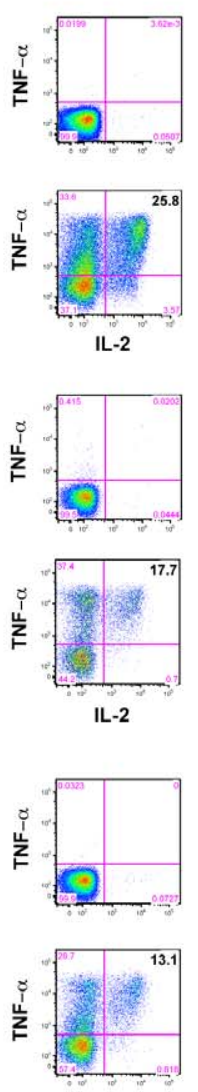

IL-2

Figure 6. TNF- $\alpha$ and IL-2 production by $\mathrm{CD4}^{+} \mathrm{T}$ cells based on CD39 and CD25 expression. The statistical difference was deemed significant using a Mann-Whitney $\mathrm{U}$ test analysis if $\mathrm{p}<0.05$. Horizontal bars denote median values. TNF- $\alpha$ and IL-2 production by CD4 ${ }^{+} \mathrm{T}$ cells from (A) one representative uninfected donor, (B) one HTLV-1 asymptomatic carrier and (C) one HAM/TSP. (D) Production of TNF- $\alpha$ and IL-2 by CD4 ${ }^{+}$T cells in $A C$ and HAM/TSP patients and uninfected donors based on CD39 and CD25 expression.

doi:10.1371/journal.pntd.0002028.g006

$\mathrm{T}$ cells and other $\mathrm{CD}^{+} \mathrm{T}$-cell subsets in HAM/TSP patients. $\mathrm{CD} 39^{+} \mathrm{CD} 25^{+} \mathrm{CD} 4^{+} \mathrm{T}$ cells from HAM/TSP produce significantly higher levels of not only IFN- $\gamma$ but also TNF- $\alpha$ and IL-2 and more importantly dual TNF- $\alpha^{+} \mathrm{IL}-2^{+}$production within the $\mathrm{CD} 39^{+} \mathrm{CD} 25^{+}$ subset when compared to HTLV-1 asymptomatic carriers or uninfected subjects. It is likely that these cells may constitute a proportion of the $\mathrm{T}_{\mathrm{HAM}}$ cells very elegantly described by Yamano $e t$ al [44]. Since expression of $H B Z$ mRNA strongly correlates with the expansion of $\mathrm{CD} 39^{+}$expressing $\mathrm{CD} 4^{+} \mathrm{T}$ cells, $\mathrm{HBZ}$ may drive the shift of these $\mathrm{T}$ cells subsets to a polyfunctional status.
Tax expression and proviral load levels have been used as markers of disease progression [13,79], but results with such markers are not consistent. Conversely, levels of HBZ mRNA were reported to strongly correlate with disease severity [27]. The positive correlation between HBZ mRNA levels and the frequency of both the $\mathrm{CD} 39^{+} \mathrm{CD} 25^{+}$and $\mathrm{CD} 39^{+} \mathrm{CD} 25^{-} \mathrm{CD} 4^{+} \mathrm{T}$ cell populations suggests that $\mathrm{HBZ}$ is associated with expansion of these immunoregulatory populations. Measuring CD $39^{+} \mathrm{CD} 25^{-} \mathrm{CD} 4^{+} \mathrm{T}$ cells frequency may be evaluated as a clinical index of disease progression to HAM/TSP as $\mathrm{CD}^{+} \mathrm{T}$ cells counts is used in HIV disease progression. 


\section{A. HTLV-1+ AC donor}

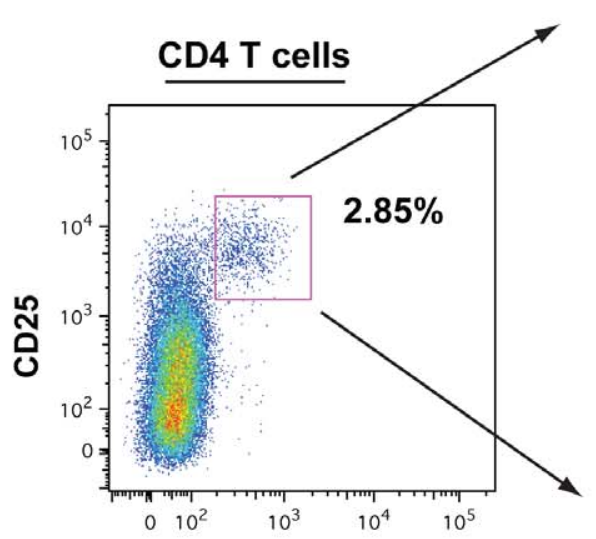

Tax
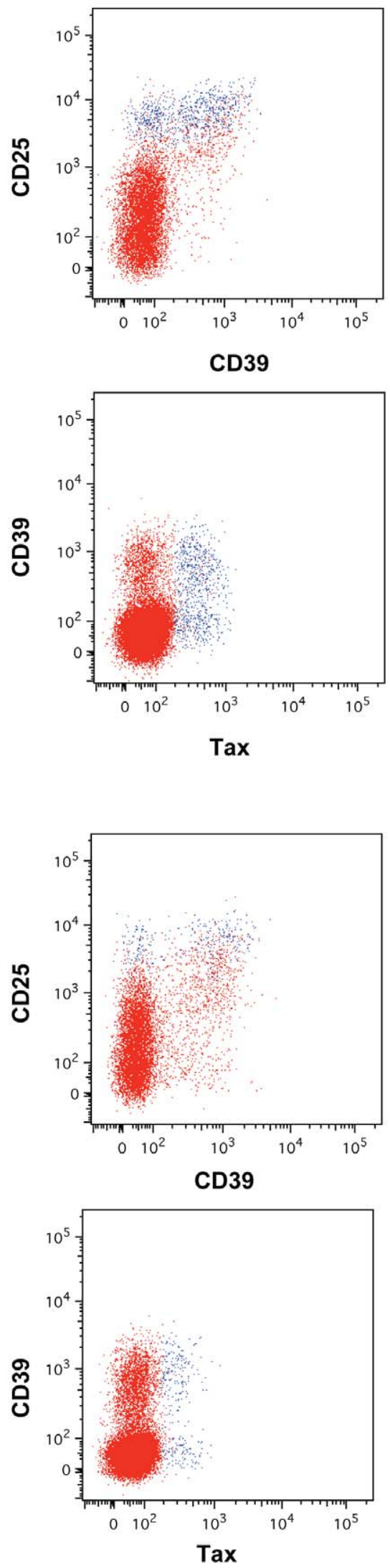

Tax
Tax expressing CD4 T cells
Tax expressing CD4 T cells

\section{B. HTLV-1+ HAM/TSP donor}

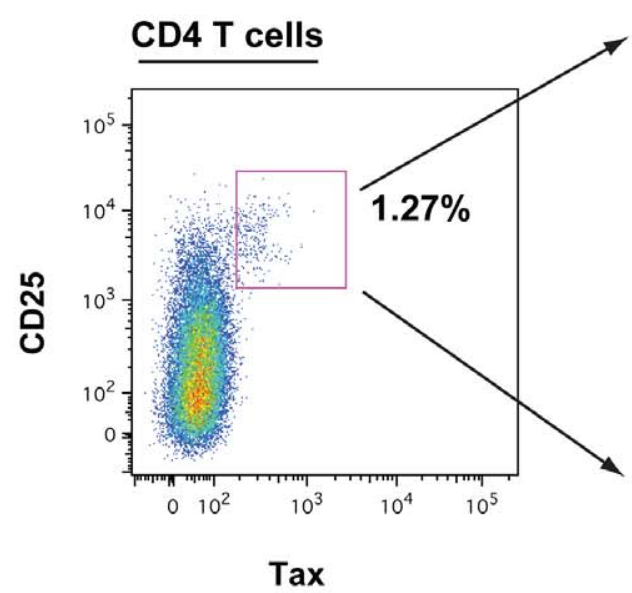

Tax

Tax expressing CD4 $T$ cells

Figure 7. Tax expression in CD4 ${ }^{+} \mathbf{T}$ cells of HTLV-1-infected subjects. Representative flow cytometry data of CD25, CD39 and Tax expression in (A) one HTLV-1-infected asymptomatic carrier and (B) one HAM/TSP patient. Plots show Tax expression restricted to $\mathrm{CD} 25^{+} \mathrm{CD} 4^{+} \mathrm{T}$ cells regardless of CD39 expression.

doi:10.1371/journal.pntd.0002028.g007 
A
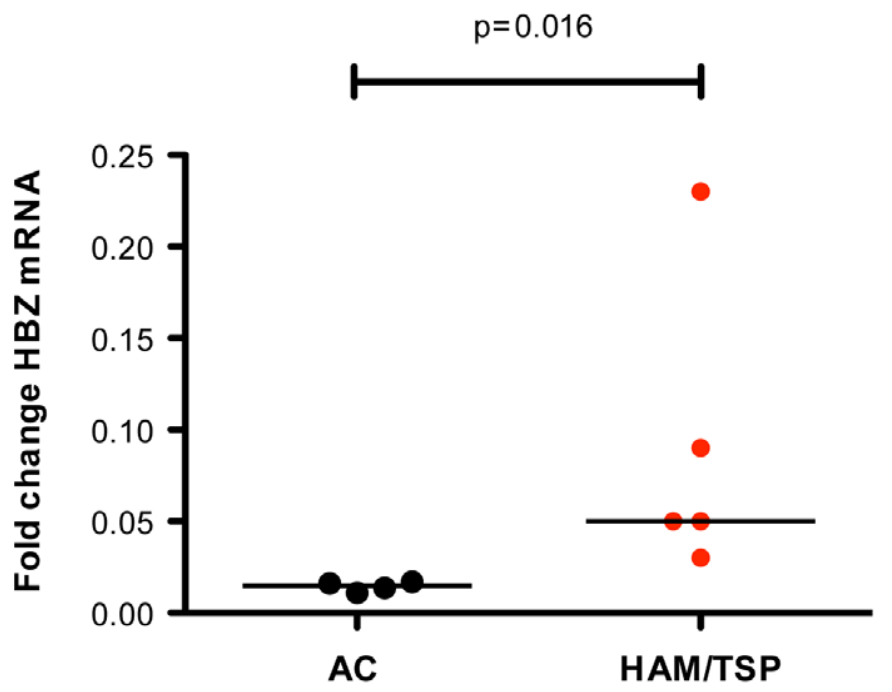

B

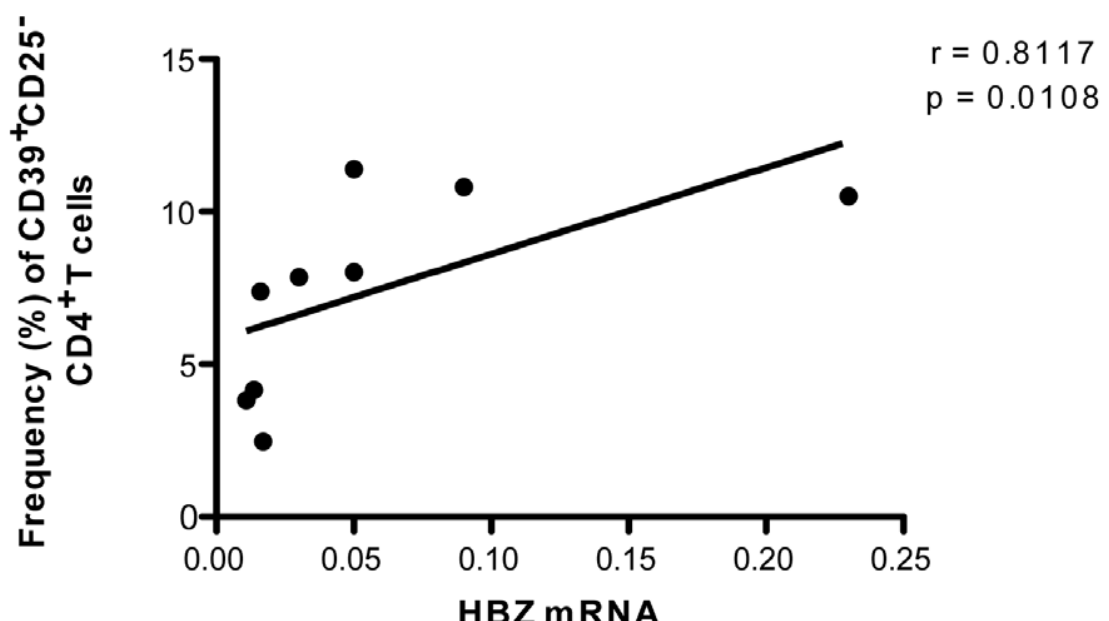

C

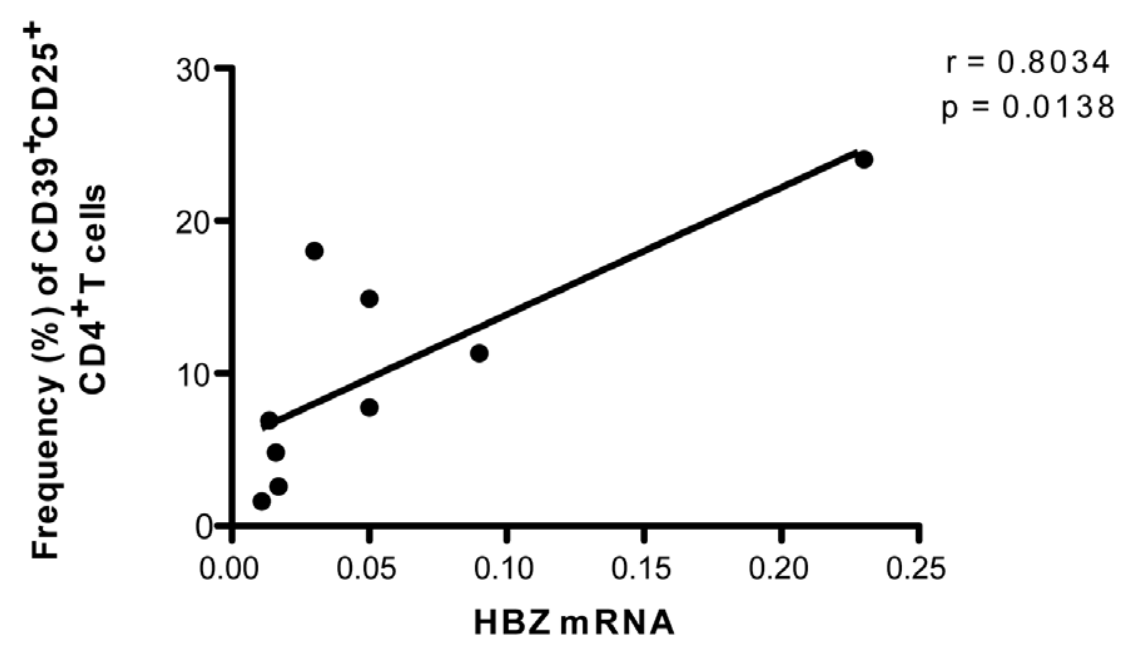

Figure 8. Relative HBZ mRNA expression. Expression was calculated as $2^{-\Delta \Delta C t}$ using the mean of $\beta$-actin as housekeeping controls. The statistical difference was deemed significant using a Mann-Whitney $U$ test analysis if $p<0.05$. Horizontal bars denote median values. (A) Fold change of HBZ mRNA expression in PBMCs of 4 ACs and 5 HAM/TSP patients. (B) Positive correlation between HBZ mRNA levels and frequencies of $\mathrm{CD} 39^{+} \mathrm{CD} 25^{-} \mathrm{CD} 4^{+} \mathrm{T}$ cells in HTLV-1-infected patients. (C) Positive correlation between HBZ mRNA level and frequency of $\mathrm{CD} 39^{+} \mathrm{CD} 25^{+} \mathrm{CD} 4^{+} \mathrm{T}$ cells in HTLV-1-infected patients.

doi:10.1371/journal.pntd.0002028.g008 
Several inflammatory cytokines have been implicated in the pathogenesis of HAM/TSP. IL-2, IFN- $\gamma$, and TNF- $\alpha$ levels are increased in HTLV-1 infection and contribute to neurological damage in HAM/TSP patients as well as in other neuroinflammatory conditions with clinical similarities to HAM/TSP such as Multiple Sclerosis [18,21,80,81]. IL-17 also plays a pivotal role in the pathogenesis of HIV infection [50,82] and various inflammatory diseases [83], but conflicting results regarding frequency of Th17 and IL-1 7 production were described in HTLV-1 infection [43,44]. We predicted Th17 cells would be increased in HAM/TSP as in other inflammatory diseases along with the rise in $\mathrm{T}$ cells with suppressive phenotype to suppress the inflammatory process. Surprisingly, the reduced number of Th17 cells in PBMC from HAM/TSP patients combined with the increased frequency of $\mathrm{CD} 4^{+} \mathrm{T}$ cells with suppressive phenotype $\left(\mathrm{CD} 39^{+} \mathrm{CD} 25^{+}\right)$resembles results of our previous studies and from others in HIV-1 infection $[50,82,84]$, where we demonstrate that IL-2 mediates expansion of $\mathrm{CD} 4^{+} \mathrm{T}$ cells expressing CD25, FoxP3, and lacking CD127, with a negative effect over Th17 cells frequency. Lower frequency of Th17 cells combined with high frequency of $\mathrm{CD}^{+}{ }^{+} \mathrm{T}$ cells with suppressive phenotype $\left(\mathrm{CD} 39^{+} \mathrm{CD} 25^{+}\right)$results in a reduced ratio of Th17 cells and CD $39^{+} \mathrm{CD} 25^{+} \mathrm{CD} 4^{+} \mathrm{T}$ cells in HAM/TSP. Thus, the polarization of $\mathrm{CD} 4^{+} \mathrm{T}$-cell responses towards Th1 in HAM/ TSP [85] may be the result or cause the hitherto imbalance of Th17 and suppressive $\mathrm{CD} 4^{+} \mathrm{T}$ cells seen in these patients. A thorough analysis of Th17 cells in the CNS of HAM/TSP patients is warranted to clarify whether this Th17 reduction is restricted to peripheral blood or if these alterations are seen in sites where the inflammatory process have clinical impact.

Changes in frequency of CD39 expressing CD4 ${ }^{+} \mathrm{T}$ cells may be an important component of the alterations seen in $\mathrm{CD} 4^{+} \mathrm{T}$-cell responses to HTLV-1 infection. Increased frequency of $\mathrm{CD}^{+} \mathrm{T}$ cells with immunostimulatory properties may be one of the missing parts to understand the development of HAM/TSP despite of increased frequency of $\mathrm{CD} 4^{+} \mathrm{T}$ cells with suppressive phenotype in this condition. To determine the frequency of CD $39^{+} \mathrm{CD}_{25}{ }^{-} \mathrm{CD} 4^{+} \mathrm{T}$ cells in HTLV-1 infection should be considered as a proxy to disease progression. Besides, reduced levels of IL- 17 and increased IFN- $\gamma$, IL- 2 and TNF- $\alpha$ confirms the skewed Th1 specificity of HTLV-1-related inflammatory alterations and immunotherapy to restore Th17 cells may be a tool to downregulate Thl responses. Finding these changes in inflammatory sites such as the CNS will determine if the prevention or reversion of these alterations may represent a valuable goal for modifying HAM/TSP clinical course.

\section{Supporting Information}

Figure S1 Dot plots of CD25, GD127 and FoxP3 expression on CD4 $^{+}$T cells. (A) FoxP3 expression in CD25 $5^{\text {hi }}$ $\mathrm{CD} 127^{\text {low }} \mathrm{CD} 4^{+} \mathrm{T}$ cells. (B) Increased proportion of $\mathrm{CD} 25^{+} \mathrm{FoxP}^{+} \mathrm{CD} 127^{\text {low }} \mathrm{CD} 4^{+} \mathrm{T}$ cells in HTLV-1-asymptomatic carriers and HAM/TSP patients compared to uninfected subjects. (TIF)

\section{References}

1. de The G, Bomford R (1993) An HTLV-I vaccine: why, how, for whom? AIDS Res Hum Retroviruses 9: 381-386.

2. Osame M, Usuku K, Izumo S, Ijichi N, Amitani H, et al. (1986) HTLV-I associated myelopathy, a new clinical entity. Lancet 1: 1031-1032.

3. Gessain A, Barin F, Vernant JC, Gout O, Maurs L, et al. (1985) Antibodies to human T-lymphotropic virus type-I in patients with tropical spastic paraparesis. Lancet 2: 407-410.

4. Mochizuki M, Watanabe T, Yamaguchi K, Tajima K, Yoshimura K, et al. (1992) Uveitis associated with human T lymphotropic virus type I: seroepidemiologic, clinical, and virologic studies. J Infect Dis 166: 943-944.
Figure S2 (A) Number of total $\mathrm{CD4}^{+} \mathrm{T}$ cells in uninfected donors, HTLV-1-asymptomatic carriers and HAM/TSP patients. (B) Proportion and $(\mathrm{C})$ number of CD $39^{-} \mathrm{CD} 25^{+} \mathrm{CD} 4^{+}$ $\mathrm{T}$ cells in uninfected donors, HTLV-1-asymptomatic carriers and HAM/TSP patients.

(TIF)

Figure S3 Expression of PD-1 on CD4 T cells of uninfected subjects, HTLV-1 asymptomatic carriers and HAM/TSP patients based on CD39 and CD25 expression. The statistical difference was deemed significant using a Mann-Whitney $\mathrm{U}$ test analysis if $\mathrm{p}<0.05$. * indicates $\mathrm{p}<0.05$. Horizontal bars denote median values. (A) PD-1 expression on $\mathrm{CD}^{+} \mathrm{T}$ cells from one representative uninfected donor, one HTLV-1-infected-asymptomatic carrier and one HAM/TSP patient. (B) Proportion of expression of PD-1 in $\mathrm{CD} 39^{+} \mathrm{CD} 25^{+}$and $\mathrm{CD} 39^{+} \mathrm{CD} 25^{-} \mathrm{CD}^{+} \mathrm{T}$ cells of uninfected donors, $\mathrm{AC}$ and HAM/TSP patients.

(TIF)

Figure S4 Correlation between HTLV-1 proviral load and frequency and number of $\mathrm{CD}^{+} \mathrm{CD}^{+} 5^{+} \mathrm{CD4}^{+} \mathrm{T}$ cells in HTLV-1-asymptomatic carriers and HAM/TSP patients. (A) Frequency of $\mathrm{CD} 39^{+} \mathrm{CD} 25^{+} \mathrm{CD} 4^{+} \mathrm{T}$ cells and (B) number of $\mathrm{CD} 39^{+} \mathrm{CD} 25^{+} \mathrm{CD} 4^{+} \mathrm{T}$ cells were plotted against proviral load of $\mathrm{AC}$ and HAM/TSP patients.

(TIF)

Figure S5 IL-17 production by the different subsets of CD4 $^{+}$T cells. (A) Th17/Tind cells ratio from number of IL-17 producing cells and frequency and number of $\mathrm{CD} 39^{+} \mathrm{CD} 25^{-}$ $\mathrm{CD}^{+}{ }^{+} \mathrm{T}$ cells of $10 \mathrm{HAM} / \mathrm{TSP}$ patients, $8 \mathrm{HTLV}-1$ asymptomatic carriers and 9 uninfected donors. Horizontal bars indicate mean values. (B) Th17/Treg cells ratio from number of IL-17 secreting cells and frequency and number of $\mathrm{CD} 39^{+} \mathrm{CD} 25^{+} \mathrm{CD} 4^{+} \mathrm{T}$ cells of $10 \mathrm{HAM}$ /TSP patients, $8 \mathrm{HTLV}-1$ asymptomatic carriers and 9 uninfected donors. The statistical differences were deemed significant using a Mann-Whitney $\mathrm{U}$ test analysis if $\mathrm{p}<0.05$. Horizontal bars indicate mean values.

(TIF)

\section{Acknowledgments}

We would like to thank Y. Tanaka (University of the Ryukus) for kindly providing anti-Tax mAb and Dr. Youko Nukui (Fundação Pro-Sangue, Hemocentro, Sao Paulo) for clinical evaluation of HTLV-1 asymptomatic carriers. We would like to thank Ravi Tandon $\mathrm{PhD}$ for guidance with qRT-PCR and Emilie Jalbert MS for flow cytometry consultations in the panel designs.

\section{Author Contributions}

Conceived and designed the experiments: FEL LGN ACS DFN EGK. Performed the experiments: FEL LCN AMH FRB KIC HWW WKN SSS. Analyzed the data: FEL LGN AMH FRB KIC HWW WKN DFN EGK. Contributed reagents/materials/analysis tools: LCN KIC SSS DFN EGK. Wrote the paper: FEL LGN WKN DFN EGK.

5. Morgan OS, Rodgers-Johnson P, Mora C, Char G (1989) HTLV-1 and polymyositis in Jamaica. Lancet 2: 1184-1187.

6. Eguchi K, Matsuoka N, Ida H, Nakashima M, Sakai M, et al. (1992) Primary Sjogren's syndrome with antibodies to HTLV-I: clinical and laboratory features. Ann Rheum Dis 51: 769-776.

7. Nishioka K, Maruyama I, Sato K, Kitajima I, Nakajima Y, et al. (1989) Chronic inflammatory arthropathy associated with HTLV-I. Lancet 1: 441.

8. Arisawa K, Soda M, Endo S, Kurokawa K, Katamine S, et al. (2000) Evaluation of adult T-cell leukemia/lymphoma incidence and its impact on non-Hodgkin lymphoma incidence in southwestern Japan. Int J Cancer 85: 319-324. 
9. Carneiro-Proietti AB, Sabino E, Leao S, Salles N, Loureiro P, et al. (2012) HTLV-1 and -2 seroprevalence, incidence and residual transfusion risk among blood donors in Brazil during 2007-2009. AIDS Res Hum Retroviruses: In Press.

10. Hisada M, Okayama A, Spiegelman D, Mueller NE, Stuver SO (2001) Sexspecific mortality from adult T-cell leukemia among carriers of human Tlymphotropic virus type I. Int J Cancer 91: 497-499.

11. Galvao-Castro B, Loures L, Rodriques LG, Sereno A, Ferreira Junior OC, et al. (1997) Distribution of human T-lymphotropic virus type I among blood donors: a nationwide Brazilian study. Transfusion 37: 242-243.

12. Orland JR, Engstrom J, Fridey J, Sacher RA, Smith JW, et al. (2003) Prevalence and clinical features of HTLV neurologic disease in the HTLV Outcomes Study. Neurology 61: 1588-1594.

13. Nagai M, Usuku K, Matsumoto W, Kodama D, Takenouchi N, et al. (1998) Analysis of HTLV-I proviral load in 202 HAM/TSP patients and 243 asymptomatic HTLV-I carriers: high proviral load strongly predisposes to HAM/TSP. J Neurovirol 4: 586-593.

14. Vine AM, Heaps AG, Kaftantzi L, Mosley A, Asquith B, et al. (2004) The role of CTLs in persistent viral infection: cytolytic gene expression in CD8+ lymphocytes distinguishes between individuals with a high or low proviral load of human T cell lymphotropic virus type 1. J Immunol 173: 5121-5129.

15. Asquith B, Mosley AJ, Barfield A, Marshall SE, Heaps A, et al. (2005) A functional CD8+ cell assay reveals individual variation in CD8+ cell antiviral efficacy and explains differences in human T-lymphotropic virus type 1 proviral load. J Gen Virol 86: 1515-1523.

16. Elovaara I, Koenig S, Brewah AY, Woods RM, Lehky T, et al. (1993) High human T cell lymphotropic virus type 1 (HTLV-1)-specific precursor cytotoxic T lymphocyte frequencies in patients with HTLV-1-associated neurological disease. J Exp Med 177: 1567-1573.

17. Kubota R, Kawanishi T, Matsubara H, Manns A, Jacobson S (2000) HTLV-I specific IFN-gamma+ CD8+ lymphocytes correlate with the proviral load in peripheral blood of infected individuals. J Neuroimmunol 102: 208-215.

18. Greten TF, Slansky JE, Kubota R, Soldan SS, Jaffee EM, et al. (1998) Direct visualization of antigen-specific T cells: HTLV-1 Tax11-19- specific CD8(+) T cells are activated in peripheral blood and accumulate in cerebrospinal fluid from HAM/TSP patients. Proc Natl Acad Sci U S A 95: 7568-7573.

19. Umehara F, Izumo S, Nakagawa M, Ronquillo AT, Takahashi K, et al. (1993) Immunocytochemical analysis of the cellular infiltrate in the spinal cord lesions in HTLV-I-associated myelopathy. J Neuropathol Exp Neurol 52: 424-430.

20. Matsuura E, Yamano Y, Jacobson S (2010) Neuroimmunity of HTLV-I Infection. J Neuroimmune Pharmacol 5: 310-325.

21. Kubota R, Kawanishi T, Matsubara H, Manns A, Jacobson S (1998) Demonstration of human T lymphotropic virus type I (HTLV-I) tax-specific CD8+ lymphocytes directly in peripheral blood of HTLV-I-associated myelopathy/tropical spastic paraparesis patients by intracellular cytokine detection. J Immunol 161: 482-488.

22. Matsuoka M, Green PL (2009) The HBZ gene, a key player in HTLV-1 pathogenesis. Retrovirology 6: 71 .

23. Gaudray G, Gachon F, Basbous J, Biard-Piechaczyk M, Devaux C, et al. (2002) The complementary strand of the human T-cell leukemia virus type 1 RNA genome encodes a bZIP transcription factor that down-regulates viral transcription. J Virol 76: 12813-12822.

24. Zhao T, Yasunaga J, Satou Y, Nakao M, Takahashi M, et al. (2009) Human Tcell leukemia virus type $1 \mathrm{bZIP}$ factor selectively suppresses the classical pathway of NF-kappaB. Blood 113: 2755-2764

25. Satou Y, Yasunaga J, Yoshida M, Matsuoka M (2006) HTLV-I basic leucine zipper factor gene mRNA supports proliferation of adult $\mathrm{T}$ cell leukemia cells. Proc Natl Acad Sci U S A 103: 720-725.

26. Hilburn S, Rowan A, Demontis MA, MacNamara A, Asquith B, et al. (2011) In vivo expression of human T-lymphotropic virus type 1 basic leucine-zipper protein generates specific CD8+ and CD4+ T-lymphocyte responses that correlate with clinical outcome. J Infect Dis 203: 529-536.

27. Saito M, Matsuzaki T, Satou Y, Yasunaga J, Saito K, et al. (2009) In vivo expression of the HBZ gene of HTLV-1 correlates with proviral load, inflammatory markers and disease severity in HTLV-1 associated myelopathy/tropical spastic paraparesis (HAM/TSP). Retrovirology 6: 19.

28. Macatonia SE, Cruickshank JK, Rudge P, Knight SC (1992) Dendritic cells from patients with tropical spastic paraparesis are infected with HTLV-1 and stimulate autologous lymphocyte proliferation. AIDS Res Hum Retroviruses 8: 1699-1706.

29. Koyanagi Y, Itoyama Y, Nakamura N, Takamatsu K, Kira J, et al. (1993) In vivo infection of human $\mathrm{T}$-cell leukemia virus type $\mathrm{I}$ in non-T cells. Virology 196: 25-33.

30. Yamano Y, Cohen CJ, Takenouchi N, Yao K, Tomaru U, et al. (2004) Increased expression of human T lymphocyte virus type I (HTLV-I) Tax11-19 peptide-human histocompatibility leukocyte antigen A*201 complexes on CD4+ CD25+ T Cells detected by peptide-specific, major histocompatibility complexrestricted antibodies in patients with HTLV-I-associated neurologic disease. J Exp Med 199: 1367-1377.

31. Richardson JH, Edwards AJ, CruickshankJK, Rudge P, Dalgleish AG (1990) In vivo cellular tropism of human T-cell leukemia virus type 1. J Virol 64: 5682 5687.
32. Mosmann TR, Coffman RL (1989) TH1 and TH2 cells: different patterns of lymphokine secretion lead to different functional properties. Annu Rev Immunol 7: 145-173.

33. Sakaguchi S, Sakaguchi N, Asano M, Itoh M, Toda M (1995) Immunologic selftolerance maintained by activated T cells expressing IL-2 receptor alpha-chains (CD25). Breakdown of a single mechanism of self-tolerance causes various autoimmune diseases. J Immunol 155: 1151-1164.

34. Harrington LE, Mangan PR, Weaver CT (2006) Expanding the effector CD4 Tcell repertoire: the Th17 lineage. Curr Opin Immunol 18: 349-356.

35. Usui T, Yanagihara K, Tsukasaki K, Murata K, Hasegawa H, et al. (2008) Characteristic expression of HTLV-1 basic zipper factor (HBZ) transcripts in HTLV-1 provirus-positive cells. Retrovirology 5: 34.

36. Goon PK, Igakura T, Hanon E, Mosley AJ, Barfield A, et al. (2004) Human T cell lymphotropic virus type I (HTLV-I)-specific CD4+ T cells: immunodominance hierarchy and preferential infection with HTLV-I. J Immunol 172: 17351743.

37. Sakaguchi S (2004) Naturally arising CD4+ regulatory t cells for immunologic self-tolerance and negative control of immune responses. Annu Rev Immunol 22: $531-562$.

38. Annunziato F, Cosmi L, Santarlasci V, Maggi L, Liotta F, et al. (2007) Phenotypic and functional features of human Th17 cells. J Exp Med 204: 18491861

39. Toulza F, Heaps A, Tanaka Y, Taylor GP, Bangham CR (2008) High frequency of CD4+FoxP3+ cells in HTLV-1 infection: inverse correlation with HTLV-1specific CTL response. Blood 111: 5047-5053.

40. Bettelli E, Carrier Y, Gao W, Korn T, Strom TB, et al. (2006) Reciprocal developmental pathways for the generation of pathogenic effector TH17 and regulatory T cells. Nature 441: 235-238.

41. Oh U, Grant C, Griffith C, Fugo K, Takenouchi N, et al. (2006) Reduced Foxp3 protein expression is associated with inflammatory disease during human $t$ lymphotropic virus type 1 Infection. J Infect Dis 193: 1557-1566.

42. Yamano Y, Takenouchi N, Li HC, Tomaru U, Yao K, et al. (2005) Virusinduced dysfunction of CD4+CD25+ T cells in patients with HTLV-I-associated neuroimmunological disease. J Clin Invest 115: 1361-1368.

43. Dodon MD, Li Z, Hamaia S, Gazzolo L (2004) Tax protein of human T-cell leukaemia virus type 1 induces interleukin 17 gene expression in T cells. J Gen Virol 85: 1921-1932.

44. Yamano Y, Araya N, Sato T, Utsunomiya A, Azakami K, et al. (2009) Abnormally high levels of virus-infected IFN-gamma+ CCR4+ CD4+ CD25+ T cells in a retrovirus-associated neuroinflammatory disorder. PLoS One 4: e6517.

45. Best I, Lopez G, Verdonck K, Gonzalez E, Tipismana M, et al, (2009) IFNgamma production in response to Tax 161-233, and frequency of CD4+ Foxp3+ and Lin HLA-DRhigh CD123+ cells, discriminate HAM/TSP patients from asymptomatic HTLV-1-carriers in a Peruvian population. Immunology 128: e777-786.

46. Maliszewski CR, Delespesse GJ, Schoenborn MA, Armitage RJ, Fanslow WC, et al. (1994) The CD39 lymphoid cell activation antigen. Molecular cloning and structural characterization. J Immunol 153: 3574-3583.

47. Borsellino G, Kleinewietfeld M, Di Mitri D, Sternjak A, Diamantini A, et al. (2007) Expression of ectonucleotidase CD39 by Foxp3+ Treg cells: hydrolysis of extracellular ATP and immune suppression. Blood 110: 1225-1232.

48. Ndhlovu LC, Leal FE, Eccles-James IG, Jha AR, Lanteri M, et al. (2010) A novel human CD4+ T-cell inducer subset with potent immunostimulatory properties. Eur J Immunol 40: 134-141.

49. Fletcher JM, Lonergan R, Costelloe L, Kinsella K, Moran B, et al. (2009) CD39+Foxp3+ regulatory $\mathrm{T}$ Cells suppress pathogenic Th17 cells and are impaired in multiple sclerosis. J Immunol 183: 7602-7610.

50. Ndhlovu LC, Chapman JM, Jha AR, Snyder-Cappione JE, Pagan M, et al. (2008) Suppression of HIV-1 plasma viral load below detection preserves IL-17 producing T cells in HIV-1 infection. AIDS 22: 990-992.

51. El Hed A, Khaitan A, Kozhaya L, Manel N, Daskalakis D, et al. (2010) Susceptibility of human Th17 cells to human immunodeficiency virus and their perturbation during infection. J Infect Dis 201: 843-854.

52. Brenchley JM, Paiardini M, Knox KS, Asher AI, Cervasi B, et al. (2008) Differential Th17 CD4 T-cell depletion in pathogenic and nonpathogenic lentiviral infections. Blood 112: 2826-2835.

53. Osame (1990) Review of WHO Kagoshima Meeting and diagnostic guidelines for HAM/TSP In: Blattner W, editor. Human Retrovirology: HTLV. New York: Raven Press. pp. 191-197.

54. Michaelsson J, Barbosa HM, Jordan KA, Chapman JM, Brunialti MK, et al. (2008) The frequency of CD127low expressing CD4+CD25high T regulatory cells is inversely correlated with human T lymphotrophic virus type-1 (HTLV-1) proviral load in HTLV-1-infection and HTLV-1-associated myelopathy/ tropical spastic paraparesis. BMC Immunol 9: 41.

55. Iannone R, Sherman MP, Rodgers-Johnson PE, Beilke MA, Mora CA, et al. (1992) HTLV-I DNA sequences in CNS tissue of a patient with tropical spastic paraparesis and HTLV-I-associated myelopathy. J Acquir Immune Defic Syndr 5: $810-816$

56. Ormsby CE, Sengupta D, Tandon R, Deeks SG, Martin JN, et al. (2012) Human endogenous retrovirus expression is inversely associated with chronic immune activation in HIV-1 infection. PLoS One 7: e41021.

57. Livak KJ, Schmittgen TD (2001) Analysis of relative gene expression data using real-time quantitative PCR and the 2(-Delta Delta $\mathrm{C}(\mathrm{T})$ ) Method. Methods 25: $402-408$. 
58. Deaglio S, Dwyer KM, Gao W, Friedman D, Usheva A, et al. (2007) Adenosine generation catalyzed by CD39 and CD73 expressed on regulatory $\mathrm{T}$ cells mediates immune suppression. J Exp Med 204: 1257-1265.

59. Dwyer KM, Hanidziar D, Putheti P, Hill PA, Pommey S, et al. (2010) Expression of CD39 by human peripheral blood CD4+ CD25+ T cells denotes a regulatory memory phenotype. Am J Transplant 10: 2410-2420.

60. Lehner $\mathrm{T}$ (2008) Special regulatory $\mathrm{T}$ cell review: The resurgence of the concept of contrasuppression in immunoregulation. Immunology 123: 40-44.

61. Hartigan-O'Connor DJ, Abel K, McCune JM (2007) Suppression of SIVspecific CD4+ $\mathrm{T}$ cells by infant but not adult macaque regulatory $\mathrm{T}$ cells: implications for SIV disease progression. J Exp Med 204: 2679-2692.

62. Ndhlovu LC, Loo CP, Spotts G, Nixon DF, Hecht FM (2008) FOXP3 expressing CD127lo CD4+ T cells inversely correlate with CD38+ CD8+ T cell activation levels in primary HIV-1 infection. J Leukoc Biol 83: 254-262.

63. Tang Q, Boden EK, Henriksen KJ, Bour-Jordan H, Bi M, et al. (2004) Distinct roles of CTLA-4 and TGF-beta in CD4+CD25+ regulatory $\mathrm{T}$ cell function. Eur J Immunol 34: 2996-3005.

64. Read S, Greenwald R, Izcue A, Robinson N, Mandelbrot D, et al. (2006) Blockade of CTLA-4 on CD4+CD25+ regulatory $\mathrm{T}$ cells abrogates their function in vivo. J Immunol 177: 4376-4383.

65. Hieshima K, Nagakubo D, Nakayama T, Shirakawa AK, Jin Z, et al. (2008) Tax-inducible production of CC chemokine ligand 22 by human $T$ cell leukemia virus type 1 (HTLV-1)-infected T cells promotes preferential transmission of HTLV-1 to CCR4-expressing CD4+ T cells. J Immunol 180: 931-939.

66. Jin HT, Anderson AC, Tan WG, West EE, Ha SJ, et al. (2010) Cooperation of Tim-3 and PD-1 in CD8 T-cell exhaustion during chronic viral infection. Proc Natl Acad Sci U S A 107: 14733-14738.

67. Tandon R, Giret MT, Sengupta D, York VA, Wiznia AA, et al. (2012) AgeRelated Expansion of Tim-3 Expressing T Cells in Vertically HIV-1 Infected Children. PLoS One 7: e45733.

68. Raimondi G, Shufesky WJ, Tokita D, Morelli AE, Thomson AW (2006) Regulated compartmentalization of programmed cell death-1 discriminates CD4+CD25+ resting regulatory T cells from activated T cells. J Immunol 176: 2808-2816.

69. Hollsberg P (1999) Mechanisms of T-cell activation by human T-cell lymphotropic virus type I. Microbiol Mol Biol Rev 63: 308-333.

70. Etoh K, Tamiya S, Yamaguchi K, Okayama A, Tsubouchi H, et al. (1997) Persistent clonal proliferation of human T-lymphotropic virus type I-infected cells in vivo. Cancer Res 57: 4862-4867.

71. Garlet GP, Giozza SP, Silveira EM, Claudino M, Santos SB, et al. (2010) Association of human $\mathrm{T}$ lymphotropic virus 1 amplification of periodontitis severity with altered cytokine expression in response to a standard periodontopathogen infection. Clin Infect Dis 50: e11-18.
72. Arnold J, Zimmerman B, Li M, Lairmore MD, Green PL (2008) Human T-cell leukemia virus type-1 antisense-encoded gene, Hbz, promotes T-lymphocyte proliferation. Blood 112: 3788-3797.

73. Bellon M, Baydoun HH, Yao Y, Nicot C (2010) HTLV-I Tax-dependent and independent events associated with immortalization of human primary $\mathrm{T}$ lymphocytes. Blood 115: 2441-2448.

74. Toulza F, Nosaka K, Tanaka Y, Schioppa T, Balkwill F, et al. (2010) Human Tlymphotropic virus type 1 -induced CC chemokine ligand 22 maintains a high frequency of functional FoxP3+ regulatory T cells. J Immunol 185: 183-189.

75. Grant C, Oh U, Yao K, Yamano Y, Jacobson S (2008) Dysregulation of TGFbeta signaling and regulatory and effector $\mathrm{T}$-cell function in virus-induced neuroinflammatory disease. Blood 111: 5601-5609.

76. Wang J, Ioan-Facsinay A, van der Voort EI, Huizinga TW, Toes RE (2007) Transient expression of FOXP3 in human activated nonregulatory CD4+ T cells. Eur J Immunol 37: 129-138.

77. Ziegler SF (2007) FOXP3: not just for regulatory T cells anymore. Eur J Immunol 37: 21-23.

78. Ohsugi T, Kumasaka T (2011) Low CD4/CD8 T-cell ratio associated with inflammatory arthropathy in human T-cell leukemia virus type I Tax transgenic mice. PLOS One 6: e18518.

79. Yamano Y, Nagai M, Brennan M, Mora CA, Soldan SS, et al. (2002) Correlation of human T-cell lymphotropic virus type 1 (HTLV-1) mRNA with proviral DNA load, virus-specific CD8(+) T cells, and disease severity in HTLV1-associated myelopathy (HAM/TSP). Blood 99: 88-94.

80. Benveniste EN, Benos DJ (1995) TNF-alpha- and IFN-gamma-mediated signal transduction pathways: effects on glial cell gene expression and function. FASEB J 9: 1577-1584.

81. Stromnes IM, Cerretti LM, Liggitt D, Harris RA, Goverman JM (2008) Differential regulation of central nervous system autoimmunity by $\mathrm{T}(\mathrm{H}) 1$ and $\mathrm{T}(\mathrm{H}) 17$ cells. Nat Med 14: 337-342.

82. Favre D, Mold J, Hunt PW, Kanwar B, Loke P, et al. (2010) Tryptophan catabolism by indoleamine 2,3-dioxygenase 1 alters the balance of TH17 to regulatory T cells in HIV disease. Sci Transl Med 2: 32ra36.

83. Kebir H, Kreymborg K, Ifergan I, Dodelet-Devillers A, Cayrol R, et al. (2007) Human TH17 lymphocytes promote blood-brain barrier disruption and central nervous system inflammation. Nat Med 13: 1173-1175.

84. Ndhlovu LC, Sinclair E, Epling L, Tan QX, Ho T, et al. (2010) IL-2 immunotherapy to recently HIV-1 infected adults maintains the numbers of IL17 expressing CD4+ T $(\mathrm{T}(\mathrm{H}) 17)$ cells in the periphery. J Clin Immunol 30: 681692.

85. Hanon E, Goon P, Taylor GP, Hasegawa H, Tanaka Y, et al. (2001) High production of interferon gamma but not interleukin-2 by human Tlymphotropic virus type I-infected peripheral blood mononuclear cells. Blood 98: 721-726. 